\title{
Towards mapping and assessing antarctic marine ecosystem services - The weddell sea case study
}

\author{
Michaela Deininger $^{\mathrm{a}, *}$, Thomas Koellner ${ }^{\mathrm{a}}$, Thomas Brey ${ }^{\mathrm{b}}$, Katharina Teschke ${ }^{\mathrm{b}}$ \\ a Professorship of Ecological Services, Faculty of Biology, Chemistry and Earth Sciences, BayCEER, University of Bayreuth, Universitaetsstr. 30,95440 \\ Bayreuth, Germany \\ b Alfred Wegener Institute, Helmholtz Centre for Polar and Marine Research (AWI), Division Biosciences/Functional Ecology, Germany
}

\section{A R T I C L E I N F O}

\section{Keywords:}

Southern Ocean

Ecosystem services

Beneficiaries

Tourism

Genetic diversity

Carbon sequestration

\begin{abstract}
A B S T R A C T
This study is the first to quantify and to map the provision of ecosystem core services (ES) - tourism, genetic diversity and carbon sequestration - for a large Antarctic marine area, the Weddell Sea. Additionally, synergies and trade-offs between the ES were explored. The analyses conducted during this study covered both spatial and temporal correlations between pairs of ES, and between individual ES and sea ice coverage. Overall, service delivery in the studied seascape is distinctly heterogeneous, albeit there are areas where multiple benefits are provided simultaneously ("super hotspots"). Our findings indicate that in wide parts of the Weddell Sea, smallscale conservation efforts may not achieve their intended goals. They also show that particularly sea ice cover restrains tourism, i.e. this sector may expect strong growth in a future of global warming driven sea ice retreat.
\end{abstract}

\section{Introduction}

In recent years, considerable attention has been drawn to the ecosystem services (ES) framework (Fisher et al., 2009; GómezBaggethun et al., 2010). This framework aligns economy with nature conservation and thereby addresses more diverse and powerful institutions and a larger source of conservation funding than past approaches (Daily and Matson, 2008; Simpson, 2011; Tallis and Kareiva, 2005). However, Burkhard et al. (2012) perceive the quantification of ES as one of the biggest challenges of current ecosystem science. The reason for this is not only a lack of appropriate methods, but also the spatial and temporal variability of ecosystems. This is especially true for the marine domain (e.g. Barbier, 2012; Costanza, 1999). The situation is aggravated by the fact that many seascapes are under-represented in global ecosystem assessments (e.g. TEEB, 2012; UNEP, 2010), and not yet the subject of any detailed regional ES assessment (Grant et al., 2013). Furthermore, the complexity of the topic lies in the fact that most ES provided by the oceans, particularly by far-off marine areas such as the Antarctic Weddell Sea, seldom have on-site beneficiaries (Grant et al., 2013). Instead, ES may support, as an example, consumption in the most diverse places in the world. For instance, markets for Weddell Sea fisheries products, such as toothfish, are mainly in Japan and North America (Catarci, 2004; see Table 1). Similarly, the Weddell Sea wildlife may contribute to the maintenance of human health, e.g. by providing chemicals that potentially have global economic importance for pharmaceutical industries.

Regulating services provided by the Weddell Sea are also beneficial to human populations on a global scale (see Table 1). For instance, the Weddell Sea plays an important role for driving global thermohaline circulation and ventilating the abyssal ocean as a considerable part of the Antarctic Bottom Water is generated in the Weddell Sea (Knox, 2007; Orsi et al., 1999). Furthermore, the Weddell Sea significantly contributes to the regulation of the global sea level just by the fact that the second largest ice shelf in Antarctica with more than $430.000 \mathrm{~km}^{2}$, the Filchner-Rønne Ice Shelf, is situated in the southern part of the Weddell Sea. Regional modelling illustrates that a potential melting of the Filchner-Rønne Ice Shelf in the second half of the 21st century would boost average basal melting of Antarctic ice shelves from $0.2 \mathrm{~m}$ per year to almost $4 \mathrm{~m}$ per year (Hellmer et al., 2013). Similarly, the Weddell Sea is a globally significant contributor to deep-sea sequestration of natural $\mathrm{CO}_{2}$ (Hoppema, 2004a, 2004b; see Table 1). Besides a long-term trend for carbon uptake, a major influencing factor on airsea $\mathrm{CO}_{2}$ exchange in the Weddell Sea is the seasonal course of biological activity (Lenton et al., 2013; Takahashi et al., 2009). The high phytoplankton growth in spring and early summer leads to a $\mathrm{CO}_{2}$ uptake, thereby lowering surface layer $\mathrm{CO}_{2}$-levels, and allowing more atmospheric $\mathrm{CO}_{2}$ to be solved in the ocean (Hoppema et al., 2000). Even if only a small amount of carbon fixed by phytoplankton attains long-term storage, more than a quarter ends up in deep waters where it is transported over large distances and only re-emerges in upwelling

\footnotetext{
* Corresponding author

E-mail address: Michaela.Deininger@gmx.de (M. Deininger).
} 
Table 1

Summary of ecosystem services provided by the Weddell Sea adapted from Costanza et al. (1997), de Groot et al. (2002) and Grant et al. (2013). Note that we evaluated the provision of ecosystem services in the Weddell Sea for an extended Weddell Sea area including the Bellingshausen Sea along the west side of the Antarctic Peninsula and the Lazarev Sea until $25^{\circ} \mathrm{E}$ (see Fig. 1).

\begin{tabular}{llll}
\hline $\begin{array}{l}\text { Ecosystem } \\
\text { services }\end{array}$ & Description & $\begin{array}{l}\text { Regional/ } \\
\text { Global } \\
\text { significance }\end{array}$ & Beneficiaries \\
& & & \\
\hline
\end{tabular}

\section{Provisioning services}

\begin{tabular}{|c|c|c|c|}
\hline $\begin{array}{l}\text { Fisheries } \\
\text { products }\end{array}$ & $\begin{array}{l}\text { Toothfish } \\
\text { (Dissostichus spp.) } \\
\text { sold mainly as high } \\
\text { value fish for direct } \\
\text { human } \\
\text { consumption. }\end{array}$ & $\begin{array}{l}\text { Total catch of } \\
189 \mathrm{t} \text { in } 2014 / 15 \\
\text { (Subarea } 48.6 ; \\
\text { SC-CAMLR, } \\
2015 \text { ). } \\
\text { Equivalent to } \\
1.6 \% \text { of total } \\
\text { reported catch in } \\
\text { the CAMLR } \\
\text { Convention Area. }\end{array}$ & $\begin{array}{l}\text { South Africa and } \\
\text { Japan operating } \\
\text { in 2014/15 (SC- } \\
\text { CAMLR, 2015). } \\
\text { Fish sold mainly } \\
\text { in Japanese and } \\
\text { US markets } \\
\text { (Catarci, 2004). } \\
\text { Additional } \\
\text { economic } \\
\text { importance for } \\
\text { (i) nations which } \\
\text { profit from } \\
\text { fishing licences, } \\
\text { (ii) port states, } \\
\text { and (iii) others } \\
\text { involved related } \\
\text { industries (Grant } \\
\text { et al., 2013). }\end{array}$ \\
\hline Fresh water & $\begin{array}{l}\text { Fresh water stored } \\
\text { in icebergs and ice } \\
\text { shelves. }\end{array}$ & $\begin{array}{l}\text { Not currently } \\
\text { used as a } \\
\text { resource but has } \\
\text { been proposed as } \\
\text { a future source of } \\
\text { freshwater for } \\
\text { other regions } \\
\text { (Grant et al., } \\
\text { 2013). }\end{array}$ & Unknown \\
\hline Photosynthesis & $\begin{array}{l}\text { Photosynthesis and } \\
\text { nutrient uptake by } \\
\text { phytoplankton, as a } \\
\text { food source for } \\
\text { higher trophic } \\
\text { levels. }\end{array}$ & $\begin{array}{l}\text { Maintains } \\
\text { Weddell Sea food } \\
\text { webs, including } \\
\text { harvested } \\
\text { species. }\end{array}$ & Global \\
\hline $\begin{array}{l}\text { Medical } \\
\text { resources }\end{array}$ & $\begin{array}{l}\text { Plants or animals } \\
\text { which provide } \\
\text { chemicals for } \\
\text { developing or } \\
\text { producing } \\
\text { pharmaceuticals or } \\
\text { industrial products. }\end{array}$ & $\begin{array}{l}\text { Unknown future } \\
\text { medical and } \\
\text { economic value } \\
\text { (Jabour-Green } \\
\text { and Nicol, 2003). }\end{array}$ & $\begin{array}{l}\text { Unknown, but } \\
\text { potentially global }\end{array}$ \\
\hline
\end{tabular}

\section{Regulating services}

Climate and air quality regulation

Weddell Sea Bottom Water, a precursor of Antarctic Bottom Water, as a driver of global thermohaline circulation and ventilation of the abyssal ocean (Orsi et al., 1999).

Regulation of global sea level.
$25-60 \%$ of the total production of bottom water in the Southern Ocean is newly formed in the Weddell Sea (Foldvik et al., 2004; Teschke et al., 2016a).

Melting of the Filchner-Rønne Ice Shelf during the 2nd half of the 21st century would contribute significantly to global sea level rise by a 20 -fold increase in average basal melting of
Table 1 (continued)

\begin{tabular}{|c|c|c|c|}
\hline $\begin{array}{l}\text { Ecosystem } \\
\text { services }\end{array}$ & Description & $\begin{array}{l}\text { Regional/ } \\
\text { Global } \\
\text { significance }\end{array}$ & Beneficiaries \\
\hline \multirow[b]{2}{*}{$\begin{array}{l}\text { Carbon } \\
\text { sequestra- } \\
\text { tion }\end{array}$} & $\begin{array}{l}\text { Uptake of } \\
\text { pollutants from the } \\
\text { atmosphere. }\end{array}$ & $\begin{array}{l}\text { Antarctic ice } \\
\text { shelves (Hellmer } \\
\text { et al., 2013). } \\
\text { Uptake of } \\
\text { pollutants } \\
\text { contributes to } \\
\text { global air quality. }\end{array}$ & Global \\
\hline & $\begin{array}{l}\text { Sequestration of } \\
\mathrm{CO}_{2} \text { by the Weddell } \\
\text { Sea. }\end{array}$ & $\begin{array}{l}\text { At present-day } \\
\text { the Weddell Sea } \\
\text { acts as a carbon } \\
\text { sink (Hoppema, } \\
2004 \mathrm{a} \text { ). The } \\
\text { amount involved } \\
\text { is } 1.9 \times 10^{13} \mathrm{~g} \mathrm{C} \\
\mathrm{yr}^{-1} \text { that is } \\
\text { equivalent to at } \\
\text { least } 6 \% \text { of the } \\
\text { presently } \\
\text { estimated world- } \\
\text { wide natural CO } 2 \\
\text { sequestration in } \\
\text { the abyssal } \\
\text { oceans } \\
\text { (Hoppema, } \\
\text { 2004b). } \\
\text { In future, climate } \\
\text { change may affect } \\
\text { the carbon } \\
\text { uptake by } \\
\text { stronger } \\
\text { upwelling in the } \\
\text { Weddell Sea that } \\
\text { brings more } \\
\text { carbon-rich deep } \\
\text { water to the } \\
\text { surface and } \\
\text { might moderate } \\
\text { the expected } \\
\text { increase of the } \\
\text { carbon sink (Le } \\
\text { Quéré et al., } \\
2007 \text { ). }\end{array}$ & Global \\
\hline $\begin{array}{l}\text { Nutrient } \\
\text { cycling }\end{array}$ & $\begin{array}{l}\text { Cycling of nutrients } \\
\text { required for plant } \\
\text { production such as } \\
\text { nitrogen, } \\
\text { phosphorus and } \\
\text { silicon (Knox, } \\
\text { 2007). }\end{array}$ & $\begin{array}{l}\text { Required for } \\
\text { maintenance of a } \\
\text { 'healthy' and } \\
\text { productive } \\
\text { Weddell Sea } \\
\text { ecosystem. }\end{array}$ & Global \\
\hline $\begin{array}{l}\text { Waste } \\
\text { treatment }\end{array}$ & $\begin{array}{l}\text { Decomposition of } \\
\text { organic wastes by } \\
\text { the biological } \\
\text { activity of } \\
\text { microorganisms. }\end{array}$ & $\begin{array}{l}\text { Required for } \\
\text { maintenance of a } \\
\text { 'healthy' and } \\
\text { productive } \\
\text { Weddell Sea } \\
\text { ecosystem. }\end{array}$ & Global \\
\hline \multicolumn{4}{|c|}{ Supporting services } \\
\hline Habitats & $\begin{array}{l}\text { Suitable living } \\
\text { space and/or } \\
\text { reproduction } \\
\text { habitat for wild } \\
\text { plants and animals. } \\
\text { Some habitats have } \\
\text { an exceptionally } \\
\text { high number of } \\
\text { species which } \\
\text { makes them more } \\
\text { genetically diverse } \\
\text { than others and are } \\
\text { known as } \\
\text { 'biodiversity } \\
\text { hotspots'. }\end{array}$ & $\begin{array}{l}\text { Required for } \\
\text { contributing to } \\
\text { conservation of } \\
\text { biological and } \\
\text { genetic diversity } \\
\text { and evolutionary } \\
\text { processes. }\end{array}$ & $\begin{array}{l}\text { Unknown, but } \\
\text { potentially global }\end{array}$ \\
\hline
\end{tabular}


Table 1 (continued)

\begin{tabular}{|c|c|c|c|}
\hline $\begin{array}{l}\text { Ecosystem } \\
\text { services }\end{array}$ & Description & $\begin{array}{l}\text { Regional/ } \\
\text { Global } \\
\text { significance }\end{array}$ & Beneficiaries \\
\hline $\begin{array}{l}\text { Genetic } \\
\text { diversity }\end{array}$ & $\begin{array}{l}\text { Genetic diversity in } \\
\text { all marine species, } \\
\text { including harvested } \\
\text { resources. }\end{array}$ & $\begin{array}{l}\text { Maintenance of } \\
\text { genetic diversity } \\
\text { to improve the } \\
\text { productivity and } \\
\text { quality of e.g. } \\
\text { crops, livestock } \\
\text { and fisheries, as } \\
\text { well as to } \\
\text { maintain healthy } \\
\text { populations of } \\
\text { wild species } \\
\text { (FAO, 2016). }\end{array}$ & $\begin{array}{l}\text { Unknown, but } \\
\text { potentially global }\end{array}$ \\
\hline \multicolumn{4}{|l|}{ Cultural services } \\
\hline $\begin{array}{l}\text { Spiritual \& } \\
\quad \text { religious } \\
\text { value }\end{array}$ & $\begin{array}{l}\text { Spiritual and } \\
\text { symbolic value of } \\
\text { the Weddell Sea as } \\
\text { an ice-bound, wild } \\
\text { and remote } \\
\text { place(AOA, 2013). } \\
\text { Particular } \\
\text { fascination also } \\
\text { comes from the fact } \\
\text { that Antarctica is } \\
\text { the only continent } \\
\text { on Earth without a } \\
\text { long history of } \\
\text { permanent human } \\
\text { population. }\end{array}$ & $\begin{array}{l}\text { Unknown, but } \\
\text { significant } \\
\text { symbolic value to } \\
\text { many people who } \\
\text { have or have not } \\
\text { visited the } \\
\text { extreme- } \\
\text { condition } \\
\text { environment } \\
\text { (Grant et al., } \\
\text { 2013). }\end{array}$ & $\begin{array}{l}\text { Unknown, but } \\
\text { potentially global }\end{array}$ \\
\hline $\begin{array}{l}\text { Tourism \& } \\
\text { recreation }\end{array}$ & $\begin{array}{l}\text { Tourist cruises, } \\
\text { yachts, scenic } \\
\text { flights, adventure } \\
\text { tourism (Grant } \\
\text { et al., 2013; } \\
\text { O'Connor et al., } \\
\text { 2009). }\end{array}$ & $\begin{array}{l}\text { Visitor numbers } \\
\text { of the most } \\
\text { popular } \\
\text { destinations in } \\
\text { the Weddell Sea } \\
\text { were between } \\
5000 \text { and } 19000 \\
\text { in } 2013 \text { / } 2014 \\
\text { season (IAATO, } \\
\text { 2016). This is, } \\
\text { however, only a } \\
\text { small fraction of } \\
\text { the average } \\
\text { annual number of } \\
\text { visitors to a city } \\
\text { museum. The } \\
\text { Weddell Sea is } 22 \\
\text { times the size of } \\
\text { Germany, but has } \\
\text { only less than } \\
\text { 10\% of the } \\
\text { number of a } \\
\text { museum's } \\
\text { visitors } \\
\text { (GOV.UK, 2016). }\end{array}$ & $\begin{array}{l}\text { Current cost of } \\
\text { tourism ranging } \\
\text { from about US } \\
\$ 8000 \text { to US } \\
\$ 15000 \text { (e.g. } \\
\text { Antarpply } \\
\text { Expeditions, } \\
2016 \text { ) limits } \\
\text { potential } \\
\text { beneficiaries to a } \\
\text { very small } \\
\text { minority of the } \\
\text { global population } \\
\text { Additional } \\
\text { economic } \\
\text { importance for } \\
\text { governments } \\
\text { charging landing } \\
\text { fees and } \\
\text { "Antarctic } \\
\text { gateway" ports }\end{array}$ \\
\hline Aesthetic value & $\begin{array}{l}\text { Wilderness areas, } \\
\text { wildlife, } \\
\text { undisturbed spaces } \\
\text { (Grant et al., 2013). }\end{array}$ & $\begin{array}{l}\text { Unknown, but } \\
\text { the Weddell Sea } \\
\text { has a globally } \\
\text { unique } \\
\text { complexity of } \\
\text { aesthetic } \\
\text { properties: } \\
\text { remoteness, } \\
\text { wind, sea ice and } \\
\text { ice shelves, } \\
\text { several species of } \\
\text { whales, dolphins } \\
\text { and seals, as well } \\
\text { as a diversity of } \\
\text { fish and seabirds } \\
\text { ((AOA, 2013; } \\
\text { O'Connor et al., } \\
\text { 2009). }\end{array}$ & $\begin{array}{l}\text { Unknown, but } \\
\text { potentially global }\end{array}$ \\
\hline
\end{tabular}

Table 1 (continued)

\begin{tabular}{|c|c|c|c|}
\hline $\begin{array}{l}\text { Ecosystem } \\
\text { services }\end{array}$ & Description & $\begin{array}{l}\text { Regional/ } \\
\text { Global } \\
\text { significance }\end{array}$ & Beneficiaries \\
\hline $\begin{array}{l}\text { Science \& } \\
\text { education }\end{array}$ & $\begin{array}{l}\text { Use of the Weddell } \\
\text { Sea for scientific } \\
\text { research, inter alia } \\
\text { research on } \\
\text { processes of } \\
\text { regional or even } \\
\text { global } \\
\text { importance(ATS, } \\
\text { 1991). }\end{array}$ & $\begin{array}{l}\text { Since over } 30 \\
\text { years the Weddell } \\
\text { Sea is the } \\
\text { geographical } \\
\text { focus area of the } \\
\text { German Antarctic } \\
\text { research. In } \\
\text { addition, there } \\
\text { are manifold } \\
\text { research } \\
\text { activities of other } \\
\text { nations. A } \\
\text { tremendous } \\
\text { amount of } \\
\text { environmental } \\
\text { and ecological } \\
\text { data exist inter } \\
\text { alia to answer } \\
\text { questions on } \\
\text { ecosystem } \\
\text { processes of } \\
\text { global } \\
\text { importance } \\
\text { (Teschke et al., } \\
\text { 2016a). } \\
\text { Unknown, but } \\
\text { potentially } \\
\text { significant media } \\
\text { attention in the } \\
\text { near future due } \\
\text { to the planned } \\
\text { CCAMLR } \\
\text { Weddell Sea } \\
\text { Marine Protected } \\
\text { Area (WSMPA). }\end{array}$ & $\begin{array}{l}\text { Unknown, but } \\
\text { potentially global }\end{array}$ \\
\hline
\end{tabular}

regions after decades or longer (Melaku Canu et al., 2015; Sabine et al., 2004a, 2004b).

The importance of supporting services provided by the Weddell Sea is merely based on the fact that a 'healthy' Weddell Sea ecosystem with biological and genetic diversity is required for maintenance of most other services (see Table 1). The Weddell Sea is very highly biodiverse, particularly in the benthos (e.g. Brandt et al., 2007; Brey et al., 1994), and apparently there is a significant number of endemic species (e.g. Clarke and Johnston, 2003; Linse et al., 2006; Mühlenhardt-Siegel, 2011), suggesting the potential as a repository of genetic diversity that cannot be sourced elsewhere. Important benefits to humans in the future may emerge due to rapid developments of modern biotechnology and biochemistry and possible future changes on the global market for genetic resources (CBD, 2010).

The Weddell Sea has no history of permanent colonization by humans. Thus, its unspoiled, undisturbed and pristine state combined with its wild and extreme environment holds particular spiritual, religious and aesthetic values for people all over the globe. Even if organized commercial tourism has hardly penetrated the central Weddell Sea, it has grown exponentially along the Antarctic Peninsula over the last years (Lynch et al., 2009). Most visitors are from the US, Australia, the UK and China, but also from Canada, Germany and France (IAATO, 2016). The educational and research value of the Weddell Sea is also an important cultural service that should not be neglected. Despite the fact that actual visits might be low, the indirect use, i.e. the environmental education about the Weddell Sea environment and its wildlife, through media, such as television, newspaper and internet, is likely to be a significant source of value. This 


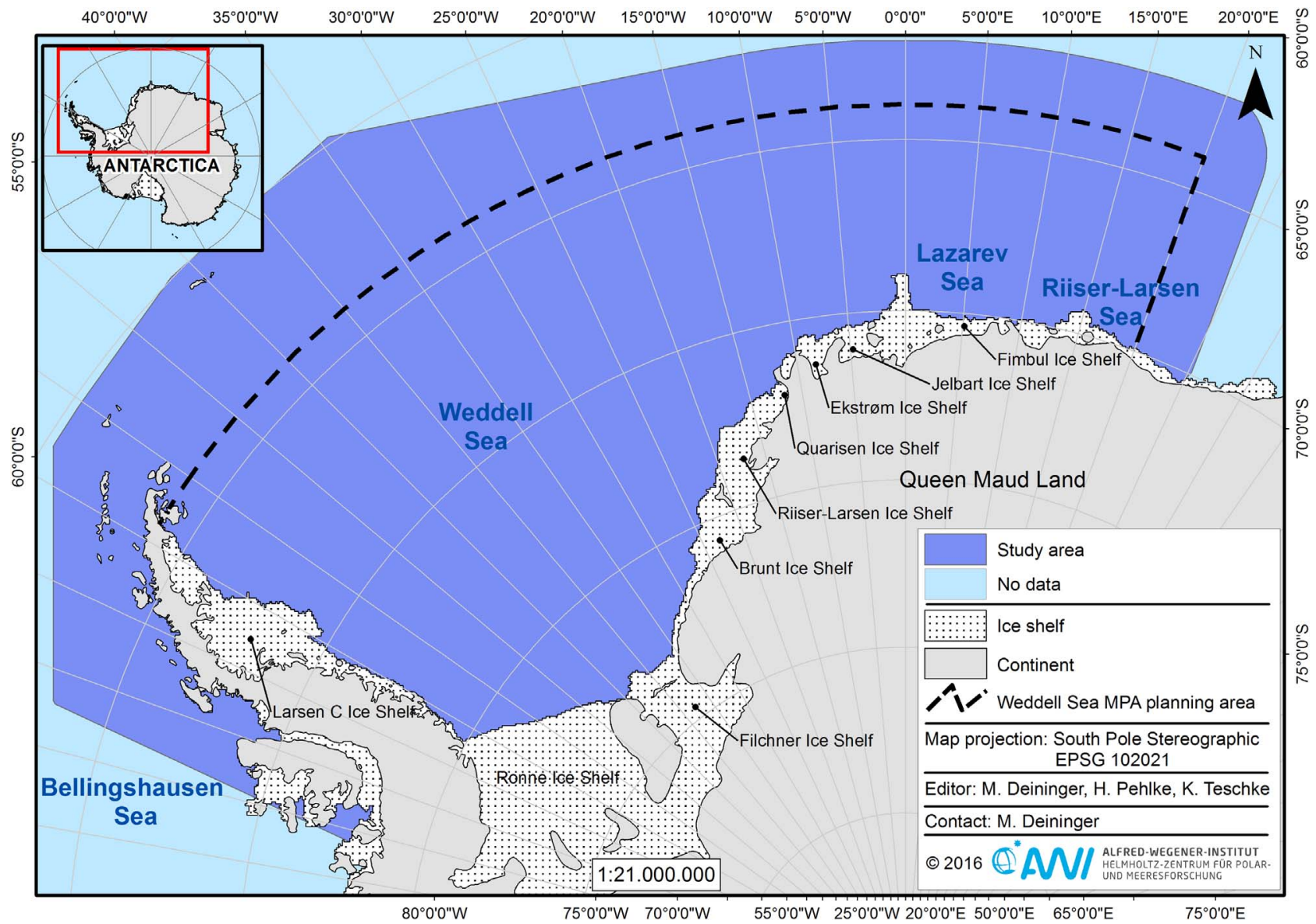

Fig. 1. Map showing the study area.

value has the potential to increase significantly as a consequence of the planned CCAMLR (Commission for the Conservation of Antarctic Marine Living Resources) Weddell Sea Marine Protected Area (WSMPA) (CCAMLR, 2015) that may attract strong media attention. In case the WSMPA is established, more data would be sampled in the course of the WSMPA Research and Monitoring Plan. This would increase the use of the Weddell Sea for scientific research and monitoring even more. Already now, compared to other Antarctic regions, the Weddell Sea is exceptionally well studied. For over 30 years the Weddell Sea has been the geographical focus area of the German Antarctic research. In addition, there are manifold research activities of other nations. A tremendous amount of environmental and ecological data exist inter alia to answer questions on ecosystem processes of global importance (Teschke et al., 2016a). In addition, the yet unrecognised non-use values of the Weddell Sea should be regarded. These are benefits derived simply from the knowledge that a good or service, such as a species or an ecosystem, exists, even if the beneficiary will never actually see or use it (Ledoux and Turner, 2002; King and Mazzotta, 2002).

Marine ecosystems are most significantly altered globally by human activity (MEA, Millennium Ecosystem Assessment, 2005a). The Millennium Ecosystem Assessment sees fishing activities as the driver with the greatest impact on living marine resources and their associated ecosystems over the last 50 years (MEA, Millennium Ecosystem Assessment, 2005b). In the case of the Weddell Sea, the threats are mainly represented by climate change and the fishing industry's increasing ambition for toothfish and krill (e.g. AOA, 2013; IPCC, 2014; MEA, Millennium Ecosystem Assessment, 2005b; Teschke et al., 2016a). Tourism might also become a determining factor in the future if the sector increases significantly (Teschke et al., 2016a). However, many parties are not fully aware of their impact on these far-off ecosystems (CBD, 2015). Also, many parties are not fully aware of the fact that they are benefiting from ecosystem functions even in the Antarctic region. In addition, there is much room for the diffusion of responsibility. This is particularly true when it comes to the conservation of the Southern Ocean marine ecosystems. A paradigm shift linking beneficiaries to ecosystem functions is of particular importance considering that the increasing (anthropogenic) pressures on natural resources alter environmental processes irreversibly (MEA, Millennium Ecosystem Assessment, 2005b). Consequently, there is an urgent need for increased credibility and transparency in ecosystem management (Daily et al., 2011; Jopke et al., 2015; Koellner, 2011). An important step in this direction is the mapping and the assessment of $\mathrm{ES}$, for example, the assessment of the way multiple ES are coupled in bundles (TEEB, 2010). Maps are effective means to characterize current benefits society derives from ecosystems. Also, they ensure transparency of trade-offs and synergies associated with decisions concerning ecosystems (Grant et al., 2013). With this, maps support the adoption of sustainable management measures, thereby contributing to human welfare and well-being (Egoh et al., 2012; Galparsoro et al., 2014). Furthermore, the United Nations have called for increased and concerted research on measuring and mapping ES (Carpenter et al., 2006; Fisher et al., 2009; Sachs and Reid, 2006). Our study extends previous knowledge, particularly because most studies so far have focused on single services only, mostly provisioning services (Tallis and Polasky, 2009; UNEP, 2011). Accordingly, the main objective of this paper is to quantify and to map the provision of three core ES - tourism, genetic diversity and carbon sequestration - for the large Antarctic Weddell Sea area. Specifically, we will evaluate synergies and trade-offs between the ES, and will explore relationships between individual ES and sea ice coverage, the latter being one of the major structuring components of the Weddell Sea environment. 


\section{Material and methods}

\subsection{Study Area}

The ongoing Weddell Sea Marine Protected Area (WSMPA) project of establishing the scientific base for identifying areas which require particular protection in the Weddell Sea provided the opportunity to select this area for our study (Teschke et al., 2016a, 2016b, 2016c). The WSMPA planning area covered by this project is defined by CCAMLR's MPA planning domains (CCAMLR, 2015), and by taking into account a bio-geographically homogeneous region, particularly on the Antarctic shelf (Teschke et al., 2016a). In our study, we extended the borders of the WSMPA planning area in order to include adjacent regions of touristic activity, such as the Bellingshausen Sea along the west side of the Antarctic Peninsula. Thus, the study area covers approximately 7.7 million $\mathrm{km}^{2}$, with an extension from $60^{\circ} \mathrm{S}$ in the north to the ice shelf margin in the south and an east-west extension from about $75^{\circ} \mathrm{W}$ to $25^{\circ} \mathrm{E}$ (Fig. 1).

The Weddell Sea study area is characterized by sea ice and its extreme seasonal variability (Fig. 2). Each summer, sea ice shrinks to approx. one third of its maximum winter extent; and ice surviving the summer melt predominantly occurs in the western Weddell Sea (Teschke et al., 2016a). The study area comprises almost the full spectrum of geomorphic features of the Southern Ocean seafloor, from about $100-5300 \mathrm{~m}$, of which some features, such as canyons and seamounts, are known to commonly support vulnerable marine
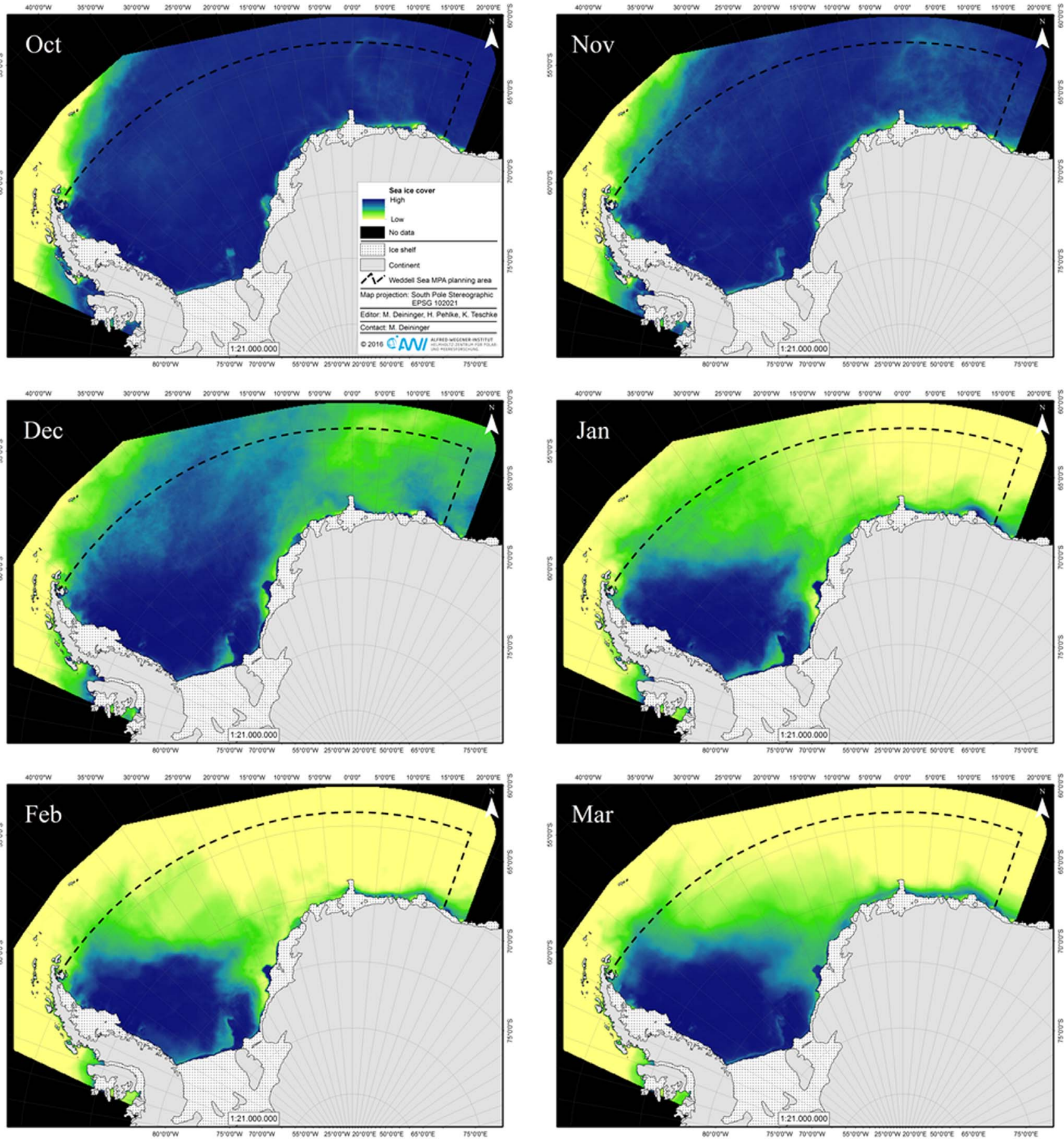

Fig. 2. Monthly mean sea ice cover (Oct to Mar 2002-2011) in the Weddell Sea study area based on AMSR-E 89 GHz sea ice concentration data (Spreen et al., 2008). 
ecosystems (Douglass et al., 2014). The Weddell Sea study area holds a key position with regard to its uniqueness, naturalness, and diversity, in combination with the likely important role in the near future in providing a place of refuge for sea ice dependent key ecosystem components, such as krill or penguins (Teschke et al., 2016a). This would portray the Weddell Sea as an underestimated ecologically and biologically significant marine area (CBD, 2012). These characteristics satisfy the criteria of the Convention on Biological Diversity for areas in need of protection on the way to a representative network of marine protected areas (Gjerde et al., 2013). The governance system of Antarctica is established by a set of international agreements also known as the Antarctic Treaty System (ATS) (Grant et al., 2013). These treaties emphasise that with every management activity impacting ecosystems particular attention is to be paid to trade-offs (ATS, 1991; Grant et al., 2013).

\subsection{Ecosystem Services (ES) assessment}

To evaluate the ES in the Weddell Sea study area, we assessed the value per unit of services followed by the mapping of services provided (Galparsoro et al., 2014; Schägner et al., 2013). In addition, trade-offs and synergies between ES were identified to evaluate the spatial correspondence of different benefits (de Groot et al., 2010; Jopke et al., 2015; Locatelli et al., 2014; Schägner et al., 2013).

The services were chosen based on the availability of data and the fact that they had to be characteristic for the study area with global significance. Hence, the following ES were quantified and mapped:

a) tourism (cultural ES)

b) genetic diversity (supporting ES)

c) carbon sequestration (regulating ES)

Because many services cannot be measured directly, we used biophysical and ecological proxies. The proxies for the respective ES were identified during interdisciplinary expert discussions (Appendix Table A.1). These discussions were particularly important to gain an overview over the state of the art. Furthermore, our selection of proxies was supported by previous studies. These, for instance, reinforce the assumption that chlorophyll $a(\operatorname{chl} a)$ concentration may serve as a useful proxy for provisioning and regulating services (de Groot et al.,
2002; Grant et al., 2006). Assuming that chl $a$ concentrations approximate primary production (e.g. Boyce et al., 2010; Moore and Abbott, 2000) and primary production is indicative of carbon sequestration (Hoppema et al., 2000), chl $a$ concentrations may be used to inform about distribution patterns of carbon sequestration in the Weddell Sea. Even if this approach is not without criticism, mainly due to the question of how reliable it is in quantitatively relating chl $a$ concentration to phytoplankton biomass (Ramaraj et al., 2013), we used chl $a$ concentration as a proxy for carbon sequestration.

Fig. 3 shows the conceptual framework in which the features of our study are embedded. This simplified diagram demonstrates that sea ice plays a critical role in the Weddell Sea inter alia with regard to accessibility and productivity (Flores, 2009; Moore and Abbott, 2000; Murphy et al., 2012). Tourism is particularly high where relatively manageable ice conditions occur, and the phytoplankton primary production increases with sea ice retreat in austral spring and summer. This seasonal drawdown of carbon by biological production leads to a carbon sink in summer (Hauck and Völker, 2015).

\subsection{Data retrieval and processing}

Following Lynch et al. (2009), data on tourist visits (excluding recreational visits by research station personnel) were provided by the International Association of Antarctica Tour Operators (IAATO). The data used reflect approximately $95 \%$ of all of the commercial cruise ships operating on the Antarctic Peninsula and approximately $90 \%$ of all the known visitors to the area (Lynch et al., 2009). Data on sitespecific landings, reaching back to the 2003-2004 season, were used for our analysis. Digital records include information on locations and time for passenger activities. Information on ship routing between stops is not included in the IAATO data. To reconstruct ship tracks from activity locations at the Antarctic Peninsula, Lynch et al. (2009) divided the Antarctic Peninsula waters into grids of squares with grid nodes spaced $6 \mathrm{~km}$ apart. Travel between nodes was permitted in the four cardinal directions. Lynch et al. (2009) conducted ship track construction using the 'GraphPath' Function in Mathematica (Wolfram Research, 2007). These reconstructed ship routes disregard routing measures designed to avoid sea ice, high winds, or other itinerant conditions. Also neglected is scenic cruising not involving passenger disembarkment. The analysis by Lynch et al. (2009) was verified by

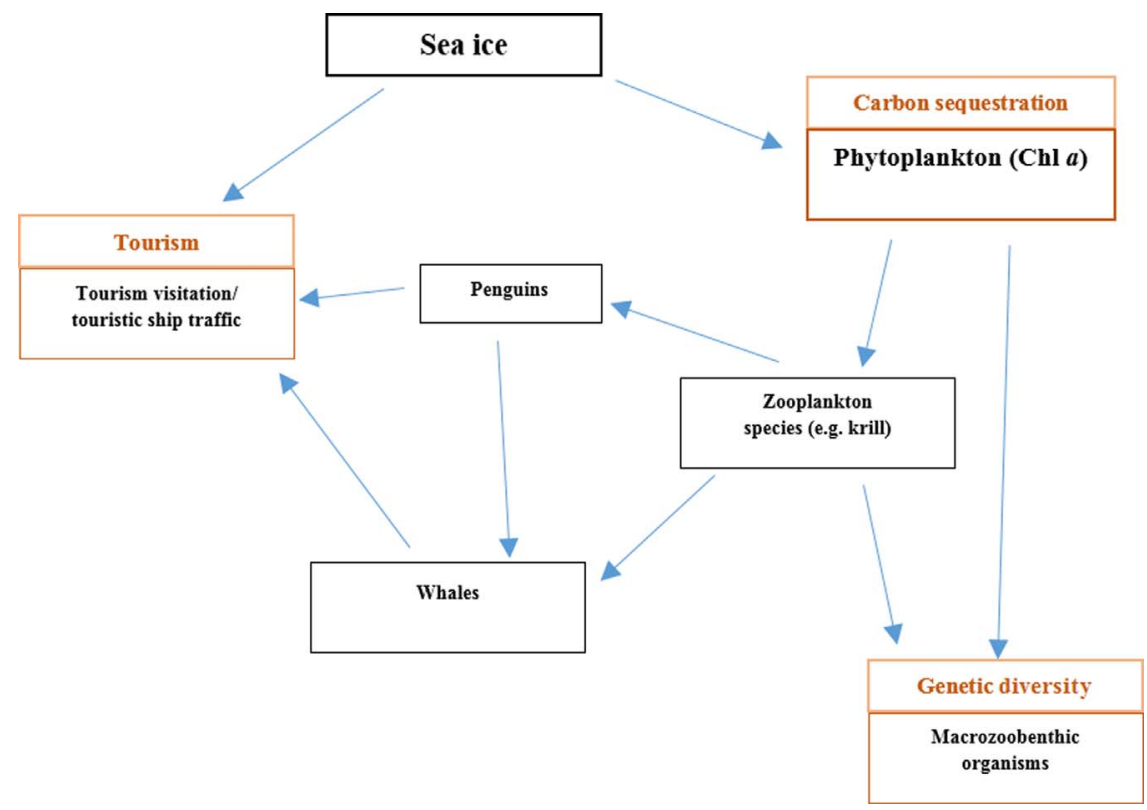

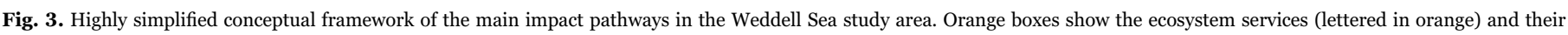

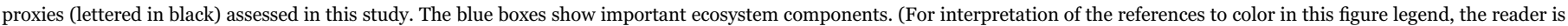
referred to the web version of this article.) 
ground truthing based on the personal knowledge of ship officers experienced in Antarctic Peninsula cruises. We calculated macrozoobenthic taxonomic richness at the level of higher taxonomic groups (class or phylum) from a partly unpublished data set held by Gerdes (Alfred Wegener Institute; e.g. Gerdes et al. (1992)) and MühlenhardtSiegel (German Center for Marine Biodiversity Research). Almost 300 macrozoobenthic samples were taken during various German Antarctic expeditions from 1984 to 2011. The number of higher taxonomic zoobenthic groups per spatial grid cell ( $1^{\circ}$ of latitude by $1^{\circ}$ of longitude) was counted. As the sampling effort does not vary strongly locally (i.e. three quarters of all sampled grid cells harbor one or two samples), we refrained from using the residuals resulting from a regression between number of samples (x) and number of higher taxonomic groups (per spatial cell, y) as one technique to reduce sampling bias.

Chl $a$ concentration derived from the Sea-viewing Wide Field-ofview Sensor (SeaWiFS) measurements for the period 1997 through 2010. The data were downloaded via NASA's OceanColor website (http://oceancolor.gsfc.nasa.gov/) as monthly level 3 standard mapped images with a spatial resolution of $9 \mathrm{~km} \times 9 \mathrm{~km}$. Data gaps were caused by clouds, ice and low incident light. Only austral summer (Nov-Mar) chl a data (log-transformed) were considered as a consequence of short day length, the inability of SeaWiFS to produce accurate chl $a$ estimates at very high solar angles and high sea ice concentration in most parts of the study area during austral winter (Moore and Abbott, 2000).

Data sets which represent features particularly important to the provisioning of ES, such as sea ice cover and flagship species (Zacharias and Roff, 2001), were additionally analysed. Regarding sea ice concentration, we calculated the total monthly average values for October to March (log-transformed), i.e. the time of austral summer, for the period 2002-2011 (Fig. 2). Satellite observations of daily sea ice concentration derived from the Advanced Microwave Scanning Radiometer - Earth Observing System (AMSR-EOS) instrument on board the Aqua Satellite. High resolution AMSR-E $89 \mathrm{GHz}$ circumAntarctic sea ice concentration maps (Jun 2002 to Oct 2011) were downloaded from the Institute of Environmental Physics, University of Bremen (http://www.iup.uni-bremen.de/). The ARTIST Sea Ice (ASI) concentration algorithm with a spatial resolution of $6.25 \mathrm{~km} \times 6.25 \mathrm{~km}$ was applied (Kaleschke et al., 2001; Spreen et al., 2008).

Data on emperor penguin (Aptenodytes forsteri) population estimates were derived from Fretwell et al. (2012, 2014). This data set was complemented by data on Adélie penguin (Pygoscelis adeliae) colonies (Lynch and LaRue, 2014; pers. comm. H. Lynch, Stony Brook University, USA). Since 2005, the nautical officers of the RV Polarstern systematically logs all sightings of cetaceans, e.g. humpback whales (Megaptera novaeangliae) and Antarctic minke whales (Balaenoptera bonaerensis), in the Southern Ocean. All sightings are stored in the database PANGAEA (http://www.pangaea.de/; Burkhardt, 2009a-i; Burkhardt, 2011, 2012, 2013a, 2013b, 2014). For mapping, we used all whale sightings, irrespective of whale species and certainty of species identification.

All data used in this study are listed additionally in the data profile in the Appendix (Table A.1).

\subsection{Spatial distribution patterns of ecosystem services}

We imported all data into QGIS (version 2.8.1 QGIS Development Team, 2015) for data representation and preparation. For all data layers, WGS 84/ NSIDC Sea Ice Polar Stereographic South (EPSGCode: 102021; http://spatialreference.org/ref/esri/102021/html/) was used. Our calculations and analyses were mainly done with $\mathrm{R}$ (version 3.1.3 R Core Team, 2015). Maps were designed using the GISsoftware ArcGIS (version 10.2.2, ESRI, 2011). The spatial distribution of the proxy values for each service was plotted on the basis of $1 \mathrm{~km} \mathrm{x}$ $1 \mathrm{~km}$ grid cells. Extreme values were kept in the data set for two reasons: firstly, the research area is quite data-poor, i.e. leaving out data points would render the analysis very difficult. Secondly, we have included the extreme values as we cannot rule out that they illustrate the spatial/temporal fluctuations of the system.

For all point data, i.e. for the data describing genetic diversity and tourism, we created interpolated raster surfaces using the Inverse Distance Weighted (IDW) function in the Spatial Analyst toolbox of QGIS 2.8.1 (see Burrough and McDonnell, 1998; Lu and Wong, 2008). To follow a more conservative extrapolation approach, we limited the IDW for the macrozoobenthic organisms by a $30 \mathrm{~km}$ buffer. This ensures that the respective sampling stations are situated within a specific benthic bioregion.

\subsection{Hotspots and coldspots}

Following Egoh et al. (2008), we considered hotspots as areas providing large proportions of a particular service, whereas coldspots refer to the opposite situation. The hotspot and coldspot information is based on average values of service delivery over the period 2003-2014.

In the scientific literature, the threshold for defining service hotspots and coldspots is inconsistent. Here, we chose the quartiles as cutoff points according to the approach mentioned in Gimona and van der Horst (2007) and Locatelli et al. (2014). Consequently, hotspots and coldspots of a given ES are areas with values in the highest and lowest $25 \%$ range of all values, respectively. For touristic visitations and touristic ship traffic, we assumed complete documentation of tourism occurrence in the raw data, i.e. missing values (NAs) were considered as coldspots. Following Qiu and Turner (2013), we identified hotspots and coldspots of more than one ES by overlaying and summing raster maps of the upper and lower 25th percentile of each service, respectively. Super hotspots and super coldspots were considered as areas with two or more services in the highest and lowest 25th percentile, respectively. Gimona and van der Horst (2007) call these areas "multifunctional hotspots", and Myers et al. (2000) speak of "the hottest hotspots“.

Since both tourism visitation and touristic ship traffic together are used to map tourism provision, these indicators are, at some points, considered as a whole. Areas where both data sets had hotspots were recorded once as a hotspot. In the case that one data set had a hotspot and the other a coldspot, a hotspot was recorded. For coldspots, the rule was that only areas where both layers had extreme lows were considered as coldspots in the new tourism layer.

\subsection{Trade-offs and synergies}

We assessed trade-offs and synergies to identify congruence or divergence between ES, and between individual ES and sea ice cover. A similar procedure was conducted by Locatelli et al. (2014). To measure the strengths of trade-offs and synergies between pairs of ES and between individual ES and ice cover, we calculated Pearson's correlations using the R package 'stats' ( $\mathrm{R}$ Core Team, 2015). Moreover, we carried out a sensitivity analysis to determine the effect of the size of the study area on the trade-offs (synergies) between individual ES and sea ice cover. Thereby, the study area was limited to a $200 \mathrm{~km}$ buffer around the permanent ice shelf for an additional correlation analysis. The objective was to only include the area in the correlation analysis that is mainly subject to the effects of sea ice cover.

\section{Results}

\subsection{Hotspots and coldspots}

The tourist landing sites in the Weddell Sea study area received on average about 1600 tourists per season (standard deviation=2897, maximum=14130, see Table 2). Sites at the northern tip of the Antarctic Peninsula were most popular. Here, the provision of cultural services was highest at Cuverville Island, followed by Goudier Island, 
Table 2

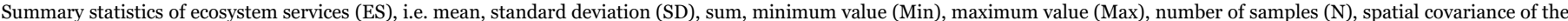

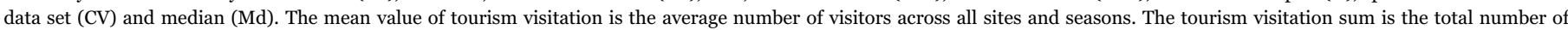

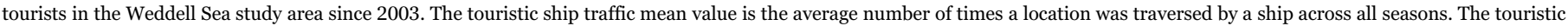
ship traffic sum is the total number of ships in the Weddell Sea study area since 2003.

\begin{tabular}{|c|c|c|c|c|c|c|c|c|c|}
\hline ES & Mean & SD & Sum & Min & Max & $\mathrm{N}$ & $\mathrm{CV}$ & Md & Unit \\
\hline Tourism visitation & 1561.93 & 2897.02 & 146821.82 & 0.00 & 14129.63 & 116.00 & 2.29 & 78.41 & Number of tourists per site and season \\
\hline Touristic ship traffic & 0.15 & 18.02 & 37275.05 & 0.05 & 169.00 & 3674.00 & 1.78 & 2.90 & Number of times a location was traversed by a ship per season \\
\hline Genetic diversity & 15.52 & 6.01 & 4144.00 & 3.00 & 32.00 & 267.00 & 0.39 & 15.00 & Individuals $/ \mathrm{m}^{2}$ \\
\hline Carbon sequestration & 0.52 & 2.34 & 0.00 & 0.05 & 56.23 & - & - & 0.40 & $\mathrm{mg} / \mathrm{m}^{3}$ \\
\hline
\end{tabular}
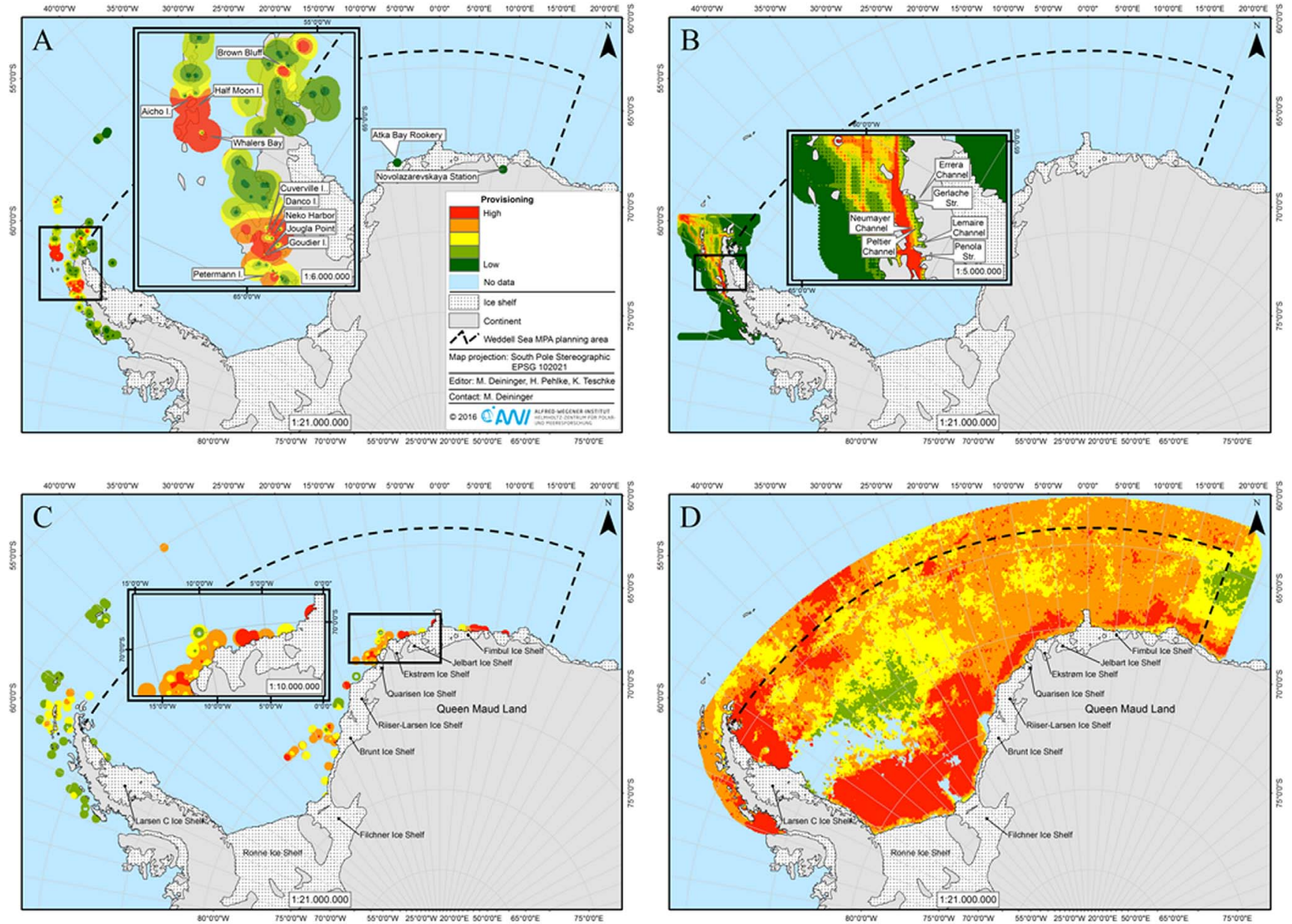

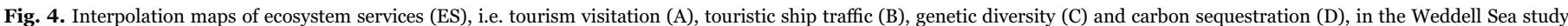

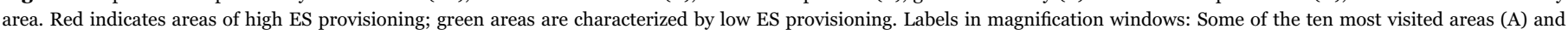

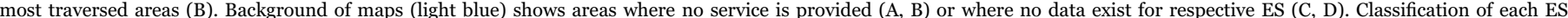

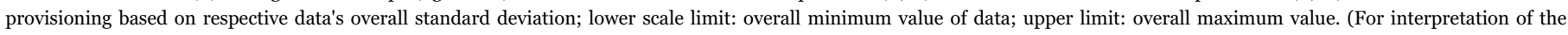
references to color in this figure legend, the reader is referred to the web version of this article.)

Whalers Bay, Neko Harbor and Half Moon Island (Fig. 4A). Distinct variation was not only evident among different destinations but also within visits of individual sites over different seasons (Appendix Table A.2, Figs. A.1 and A.2). Even Cuverville Island, the most visited site, showed these variations. Its peak in visitation during the 2007/2008 season (about 20000 visitors) was followed by a steady decrease with a minimum in 2011/2012 with about 10000 visitors. In the following years, Cuverville Island was characterized by steadily increasing numbers of visitors with two peaks in 2012/2013 and 2013/2014. The two tourist destinations in the eastern Weddell Sea, Atka Bay Rookery (Atka Iceport) and Novolazarevskaya Station, showed quite low tourism provision with an average of about 30 tourists per season (Fig. 4A). Some sites were only sporadically stopped at and did not receive visitors for several seasons (see Appendix Table A.2, Figs. A.1 and A.2). This explains the quite large standard deviation in some cases. Some places of interest no longer seem to be on the agenda of current tours, since they have not shown tourism activity for up to eight years (e.g. Dorian Bay, Intercurrence Island, Madder Cliffs). The same low service provision applied to Novolazarevskaya Station, which was only visited four times during the last 11 seasons. The concentration of tourism visitation was reflected in the pattern of marine traffic (Fig. 4B) (Lynch et al., 2009). Marine traffic volume was largest in the Gerlache 

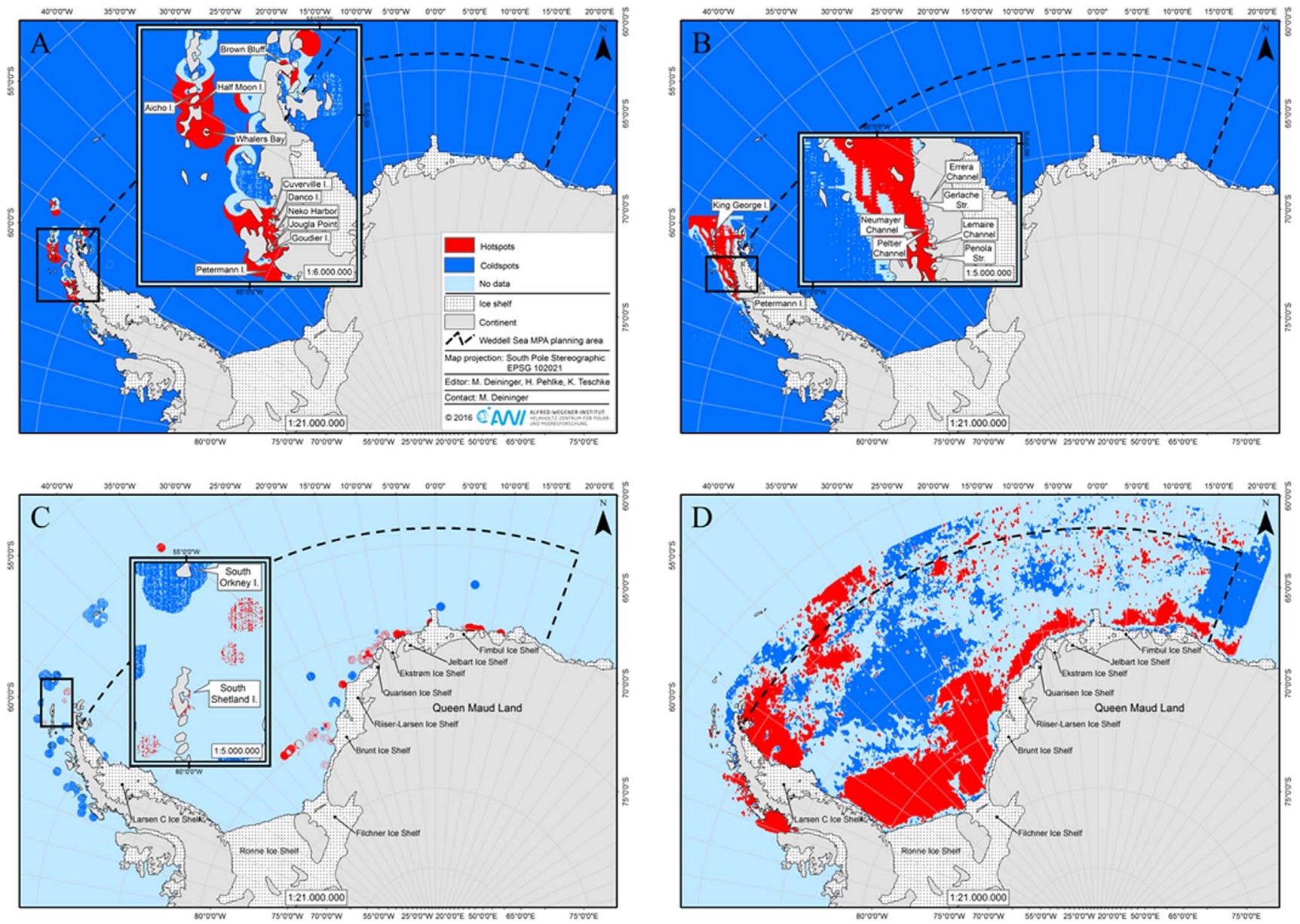

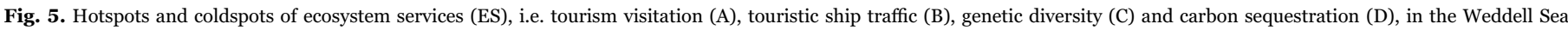

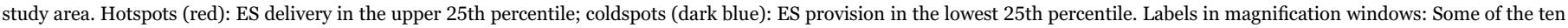

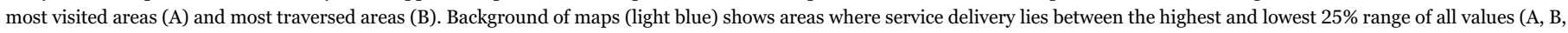
$\mathrm{C}, \mathrm{D})$ or where no data exist for respective ES (C, D). (For interpretation of the references to color in this figure legend, the reader is referred to the web version of this article.)

Table 3

Correlation coefficients (r) between ecosystem services (ES) and between ES and mean sea ice cover; ${ }^{*}=\mathrm{p}<0.05$. The first $\mathrm{r}$ of the Pearson's correlations between individual ES and mean sea ice cover refer to the calculation for the whole study area; the second $r$ values are calculated for the limited study area $(200 \mathrm{~km}$ buffer around the permanent ice shelf).

\begin{tabular}{|c|c|c|c|c|}
\hline & $\begin{array}{l}\text { Tourism } \\
\text { visitation }\end{array}$ & $\begin{array}{l}\text { Touristic } \\
\text { ship traffic }\end{array}$ & $\begin{array}{l}\text { Genetic } \\
\text { diversity }\end{array}$ & $\begin{array}{l}\text { Carbon } \\
\text { sequestration }\end{array}$ \\
\hline $\begin{array}{l}\text { Tourism } \\
\text { visitation }\end{array}$ & 1.00 & $0.32 *$ & 0.19 & 0.03 \\
\hline $\begin{array}{l}\text { Touristic ship } \\
\text { traffic }\end{array}$ & $0.32^{*}$ & 1.00 & 0.22 & $-0.31^{*}$ \\
\hline Genetic diversity & 0.19 & 0.22 & 1.00 & 0.09 \\
\hline $\begin{array}{l}\text { Carbon } \\
\text { sequestration }\end{array}$ & 0.03 & $-0.31^{*}$ & 0.09 & 1.00 \\
\hline Oct sea ice & $\begin{array}{l}-0.25^{*} \\
-0.52^{*}\end{array}$ & $\begin{array}{l}-0.47^{*} \\
-0.80^{*}\end{array}$ & $\begin{array}{l}-0.41^{*} \\
-0.32^{*}\end{array}$ & $0.29 \mid 0.64 *$ \\
\hline Nov sea ice & $\begin{array}{l}-0.30^{*} \\
-0.58^{*}\end{array}$ & $\begin{array}{l}-0.41^{*} \\
-0.74^{*}\end{array}$ & $\begin{array}{l}-0.36^{*} \\
-0.29^{*}\end{array}$ & $0.30 \mid 0.63^{*}$ \\
\hline Dec sea ice & $\begin{array}{l}-0.12^{*} \mid \\
-0.55^{*}\end{array}$ & $\begin{array}{l}-0.21^{*} \mid \\
-0.71^{*}\end{array}$ & $\begin{array}{l}-0.03 \mid \\
-0.27^{*}\end{array}$ & $0.40 \mid 0.59 *$ \\
\hline Jan sea ice & $\begin{array}{l}0.11 \mid \\
-0.55^{*}\end{array}$ & $\begin{array}{l}0.12 \mid \\
-0.50^{*}\end{array}$ & $\begin{array}{l}0.17 \mid \\
-0.11\end{array}$ & $0.17 \mid 0.38^{*}$ \\
\hline Feb sea ice & $\begin{array}{l}0.16 \mid \\
-0.28^{*}\end{array}$ & $0.19 \mid-0.18$ & $0.36 \mid 0.14$ & $0.16 \mid-0.04$ \\
\hline Mar sea ice & $0.12 \mid-0,18$ & $0.12 \mid-0,13$ & $0.39 \mid 0,13$ & $0.25 \mid-0,07$ \\
\hline
\end{tabular}

Strait, Errera Channel, Neumayer Channel, Peltier Channel, Lemaire Channel, and the Penola Strait regions (Lynch et al., 2009). Here, locations were traversed by a ship up to 169 times per season between 2003 and 2008 (Table 2). While hotspots of tourism visitation and touristic ship traffic only occur at the Western Antarctic Peninsula, most of the study area shows tourism coldspots (Fig. 5A, B).

As to the spatial distribution pattern of the supporting service genetic diversity, a maximum of 32 different macrozoobenthic taxa at the level of higher taxonomic groups occurred in the study area. No area showed fewer than three taxa with an average number of 16 (Table 2). However, standard deviation was quite high. Primarily, the macrozoobenthos shows a patchy distribution pattern regarding the number of higher taxonomic groups (Fig. 4C). There was a relatively low number of benthic taxa (mean number of taxa $=11$; results not shown) at the Antarctic Peninsula, with some exceptions around the South Shetland Islands. In contrast, in the eastern part of the study area, along Queen Maud Land coast from Fimbul Ice Shelf in the East to Brunt Ice Shelf in the south-east, the number of higher benthic taxa was quite large (mean number of taxa $=19$; results not shown). In addition, there was a higher number of benthic taxa east of South Orkney Islands in the very north of the study area (mean number of taxa $=16$; results not shown). In summary, hotspots of genetic diversity made up about $1 \%$ of the study area with most hotspots on the eastern and south-eastern Weddell Sea shelf (Fig. 5C).

Overall, in most parts of the study area, carbon sequestration was relatively low (mean chl $a$ concentration $\leq 0.5 \mathrm{mg} / \mathrm{m}^{3}$ ) (Table 2). 

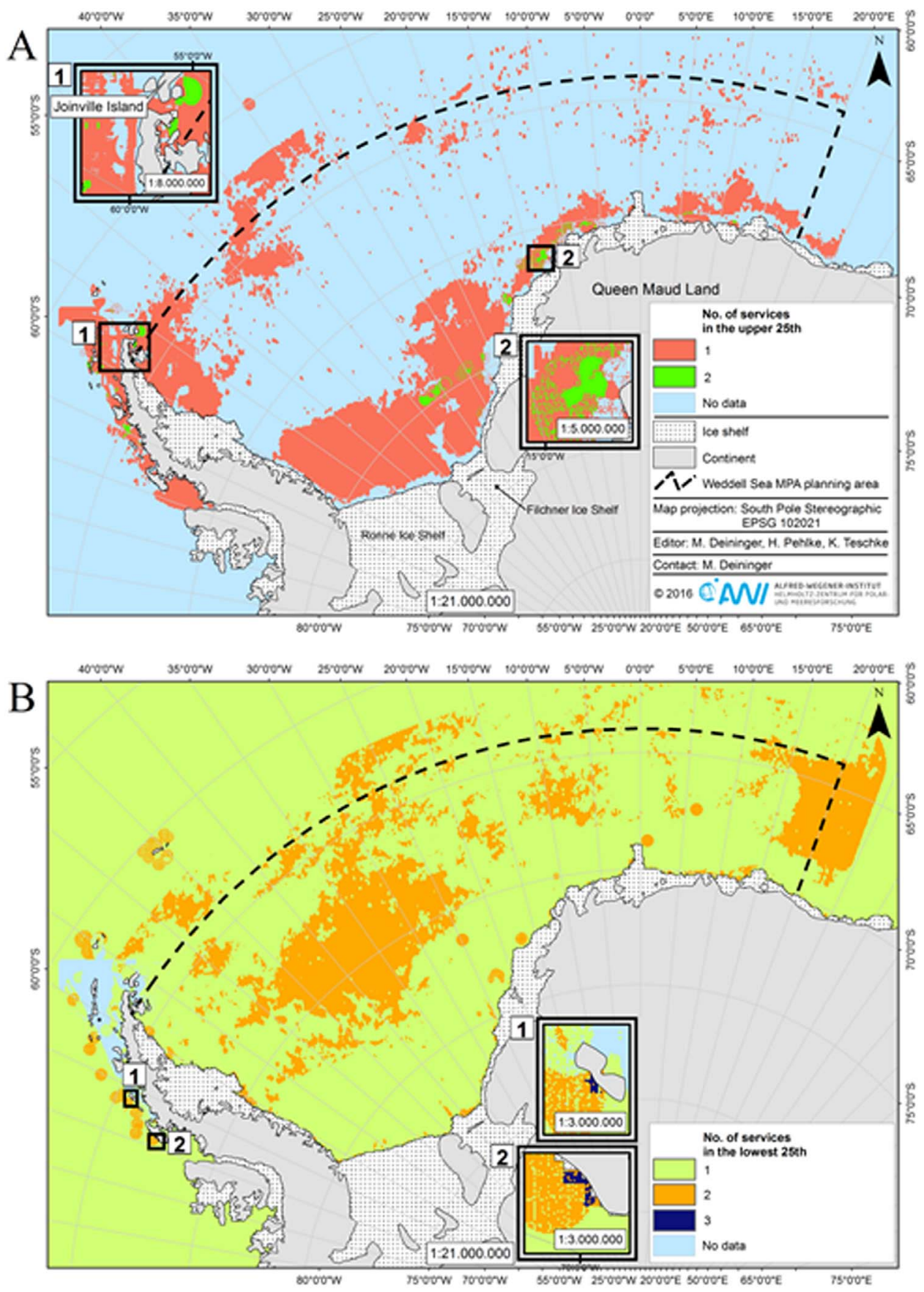

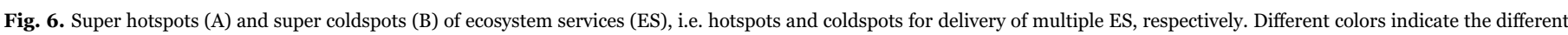
number of ES in the upper and lower 25th percentile, respectively.

Maximum values of carbon sequestration occurred in the coastal waters along the Antarctic Peninsula (e.g. near Larsen C Ice Shelf) and the coast of Queen Maud Land (Fig. 4D). High provisioning of the ES also occurred in the southern Weddell Sea, i.e. offshore Ronne Ice Shelf and east of Filchner Trough. Service hotspots of carbon sequestration occurred with $13.9 \%$ over relatively large portions of the study area (Fig. 5D).

\subsection{Trade-offs and synergies between ES}

Correlations between the ES tourism, genetic diversity, and carbon sequestration were not significant except for the relationship between carbon sequestration and touristic ship traffic $(\mathrm{r}=-0.31, \mathrm{p}<0.05)$
(Table 3; Appendix Fig. A.3). Moreover, a significant positive relationship existed within the ES tourism, i.e. between tourism visitation and touristic ship traffic $(\mathrm{r}=0.32, \mathrm{p}<0.05)$.

There were significant moderate to strong negative correlations between sea ice cover from October to November and both parameters tourism and genetic diversity, respectively (Table 3; Appendix Fig. A.4). In January to March correlations were no longer significant. Carbon sequestration and sea ice cover showed a weak positive correlation only. However, the sensitivity analysis yielded clear significant correlations between sea ice cover and carbon sequestration from October to January (Table 3; Appendix Fig. A.5).

The ES hotspots and coldspots in the study area showed no significant relationships (Appendix Table A.3). There was only one 


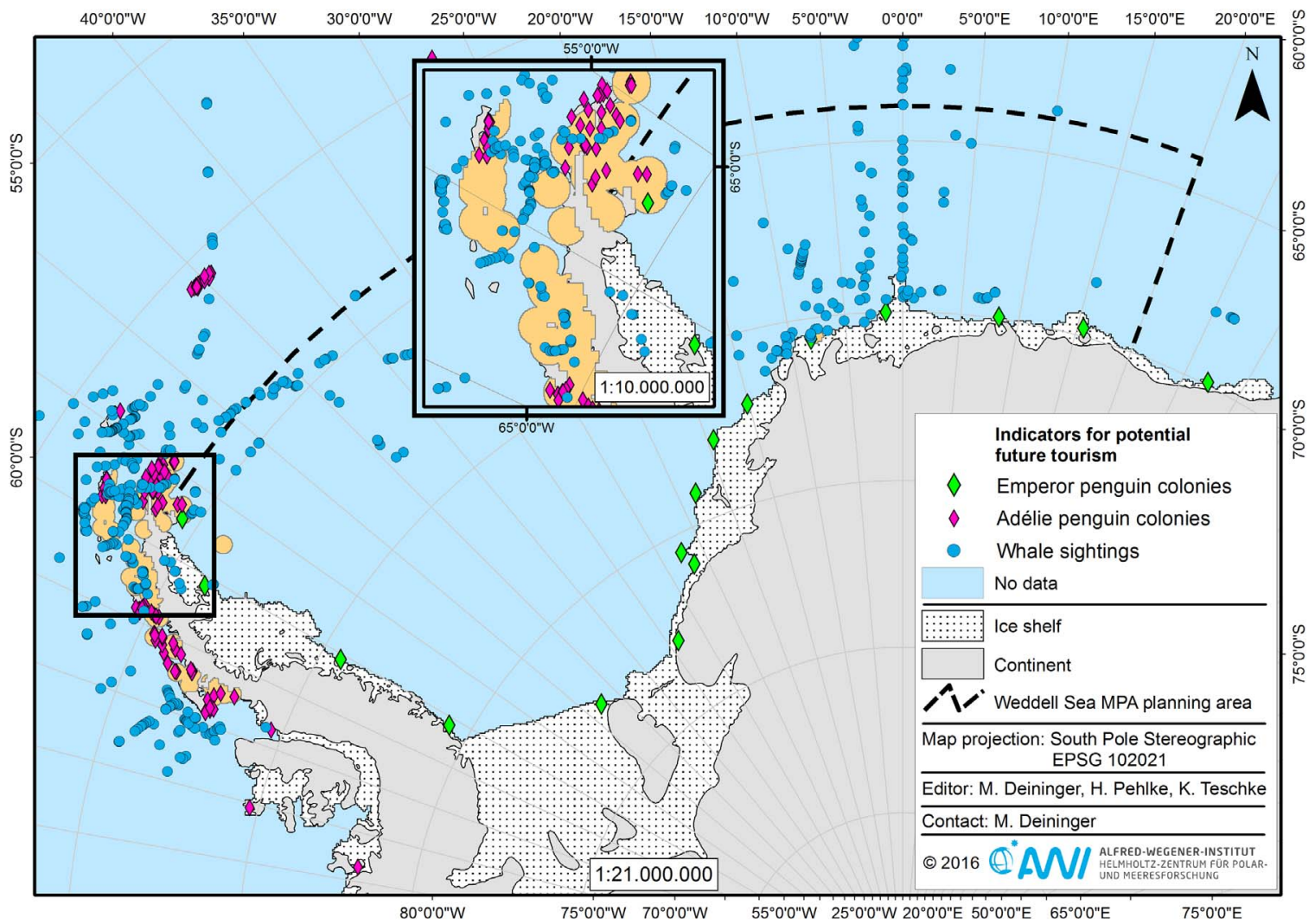

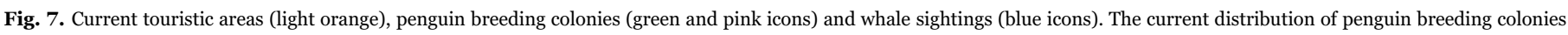

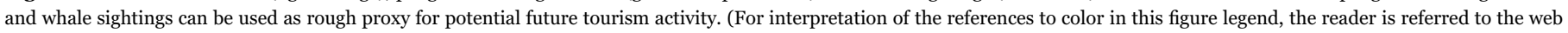
version of this article.)

significant correlation between hotspots of tourism and coldspots of tourism $(\mathrm{r}=-0.75, \mathrm{p}<0.05)$. Nevertheless, there were areas where high values of multiple benefits coincide (i.e. super hotspots) (see Fig. 6). These regions are located around the Antarctic Peninsula (e.g. at Joinville Island) and along Queen Maud Land coast towards RonneFilchner Ice Shelf. However, these super hotspots represent a relatively small area of the study area $(0.44 \%)$. Yet, in large areas at least one service was provided to the highest level. Even if coldspots of ES were spread all across the study area, only small locations showed low supply of all services (Fig. 6). Thus, super coldspots made up only very small fractions of the study area.

\section{Discussion}

\subsection{Spatial distribution patterns of ecosystem services}

The evaluation of synergies and trade-offs between the ES showed no significant correlations except for the relationship between carbon sequestration and touristic ship traffic. This may be due to the fact that there is quite a long cascade of ecosystem components and functions between chl $a$ and the other services (e.g. Murphy et al., 2012; Nicol and Raymond, 2012). The functional link from phytoplankton over zooplankton and apex predators (e.g. seals, whales) to tourist visitation does not translate into a visible spatial pattern, maybe owing to the high spatio-temporal mismatch of the various components. For example, a lag of weeks to months between primary production and changes in zooplankton can occur, depending on species, water temperature and other hydrographic characteristics (Thompson et al., 2012). Further time lags between zooplankton and fish biomass, and, finally, between forage fish and marine mammals are known (e.g. Croll et al., 2005). Furthermore, it seems that the subsequent links to tourism are more multidimensional and multifactorial. For instance, tourist activ- ities do not only involve animal watching (O’Connor et al., 2009). There are more tourist attractions independent of $\operatorname{chl} a$, such as visiting the icecaps and glaciers of the islands and coasts (Oceanwide Expeditions, 2015).

The exploration of the relationships between individual ES and sea ice coverage as one of the major structuring components of the Weddell Sea environment showed that sea ice cover in austral spring significantly correlates with tourism and genetic diversity, respectively. In austral spring, sea ice cover is usually still close to the maximum winter extent (Teschke et al., 2016a). Thus, it does not only have a direct negative effect on tourism by limiting accessibility, it also has indirect negative effects on the provision of this ES. This is because whales, for example, depend on ice free areas to breathe (e.g. Gill and Thiele, 1997), and penguins use those areas to reach open water (Zimmer et al., 2008). In austral summer, however, there are no more significant adverse effects of sea ice cover on the provision of ES. During this time, the study area is characterized by relative widespread ice-free conditions with a sea ice minimum in February (Teschke et al., 2016a).

The finding that tourism is significantly negatively correlated with sea ice conditions complies with the pelagic regionalization of the Southern Ocean by Raymond (2011). Following this regionalization, more than half of the hotspots of tourism activity are located in areas subject to challenging ice conditions most of the year (results not shown). However, it should be noted that the large coldspots of tourism provision off the Antarctic Peninsula are also likely to be a consequence of the distance to coast. Most tours begin and end their journey from Ushuaia, Argentina (Lynch et al., 2009). Consequently, sites in the eastern part of the study area are too remote compared to the sites the Weddell Sea voyages visit usually.

In contrast to the clear relationship between sea ice and tourism, it was initially unclear why carbon sequestration shows only low correlations with sea ice cover. An important body of literature shows that chl 
$a$ concentration and sea ice are closely linked in space and time with sea ice retreat leading to strong phytoplankton blooms (e.g. Flores, 2009; Moore and Abbott, 2000). The melting of sea ice enhances photosynthetic productivity owing to water column stratification and the release of ice algae and nutrients from the melting ice. However, while our correlation analysis of the whole study area does not indicate a relationship between chl $a$ concentration and sea ice cover, the sensitivity analysis, focusing on a $200 \mathrm{~km}$ buffer around the permanent ice shelf, shows significant positive correlations between both parameters. This result supports the fact that a high background noise, i.e. a high spatial variation of sea ice cover or chl $a$ concentration within the study area, leads to non-significant correlation patterns.

In this study, the ES hotspots are spread across large portions of the study area. However, they were not spatially concordant, i.e. there was no significant spatial correlation. The heterogeneity of services delivery, in combination with the low level of spatial congruence, suggests that the entire area is important for ES provision. Our results coincide quite well with the findings reported by Egoh et al. (2008), and indicate that caution should be exercised when focusing conservation efforts on smaller areas. Due to the weak correlations between the ES in the study area, it is not advisable to use one service to plan for other services (Egoh et al., 2008). Protecting a hotspot area of one service does not necessarily also enhance the provisioning of other services. Nevertheless, it is not clear from the study whether or not trade-offs or synergies could occur over time (Raudsepp-Hearne et al., 2010). This is especially true in the light of the strong temporal variability of some of the ES (e.g. carbon sequestration) and the large uncertainties with regard to the development of the two most important drivers of change in the study area: global warming and fishing.

\subsection{Future changes - tourism activity and beyond}

Tourism focuses mainly on occurrence of charismatic species such as whales (e.g. killer whales, humpback whales, minke whales) and penguins (e.g. Adélie penguins, Emperor penguins). This means that provision of the ES tourism is particularly high where these species occur and where they are accessible (Oceanwide Expeditions, 2015), i.e. where relatively manageable ice and weather conditions occur. Sea ice conditions, distance to the coast and harsh weather conditions are the reason why only relatively small areas of the Weddell Sea have been identified as providing cultural services so far (Ghermandi et al., 2012). Nevertheless, it is likely that in future these services will increase their value and distribution in the region due to global climate change (Ghermandi et al., 2012; O'Donnell et al., 2011). Surface air and seawater temperatures have increased around the Western Antarctic Peninsula (WAP). As a consequence, glaciers on the WAP and on nearby islands retreat and even collapse and the annual period of sea ice cover have shortened (e.g. Stammerjohn et al., 2008; Turner et al., 2005; Whitehouse et al., 2008). This is very likely to lead to a temporal and spatial increase in tourism activity around the Peninsula region (see Fig. 7). This trend is already recognizable with the tourism season starting earlier and ending later than ten years ago (Lynch et al., 2009). Moreover, O'Connor et al. (2009) have already confirmed that the demand for whale watching in the Antarctica region has grown strongly in recent years.

It is also likely that in forthcoming decades provisioning services (e.g. fisheries products) will increase by the fact that the fishery could open up new fishing grounds in the Weddell Sea due to projected longterm climate change. For example, the krill fishery may shift further south into the Weddell Sea to follow most favourable krill habitats (Hill et al., 2013; Teschke et al., 2016a). Furthermore, a reasonable sized standing stock of Dissostichus mawsoni can be assumed from exploratory long-line fisheries in the Weddell Sea (Teschke et al., 2016a). These stocks require extremely careful management because the consequences of overexploitation are even more severe for long-lived, slow-growing species with late maturity such as the Antarctic toothfish.
If access to Weddell Sea fishing grounds becomes less restricted by sea ice, illegal, unreported and unregulated (IUU) fishing may become a major concern. Besides direct consequences of IUU fishing, such as the reduction or even the elimination of the toothfish stock, indirect results may be irreversible changes in the marine community structure and energy flow (Teschke et al., 2016a).

Activities concerning abiotic resources like minerals and fossil fuels are further possible future uses of area that becomes less restricted by sea ice. The millennium Ecosystem Assessment (2005) states that given appropriate economic incentives, seabed mining for minerals (e.g. gold, diamonds, tin) is already under way. Practical technology to extend mining for a range of minerals into the deep sea is also being developed (Wiltshire, 2001). However, today and in the foreseeable future, human activities in the Weddell Sea, except for research, fisheries and tourism, are prohibited under the Antarctic Treaty and its Protocol on Environmental Protection (Teschke et al., 2016a).

\subsection{Limitations and strengths of the study}

One major shortcoming of this study is the spatial mismatch between data of different ES indicators and/or sea ice. This irregular data coverage is likely to bias the results. The limitations in each of the data sources are recognized.

Also, evaluating correlations between ES as trade-offs (negative correlations) and synergies (positive correlations) is quite a common approach and also applied by e.g. Jopke et al., (2015) and Locatelli et al. (2014). However, this understanding of trade-offs and synergies might differ from that of other researchers, e.g. Grant et al. (2013) who could argue that assessing spatial correlations is not enough to assess interconnections between ES but gives only information on co-locations of ES. Nevertheless, also in view of the conceptual framework of the main impact pathways in the Weddell Sea study area we summarized (Fig. 3), it should become clear that the correlations do not merely show co-locations but actually interactions between ES.

Looking at the ES mapping approach applied, several points worth discussing emerge. One major issue refers to questions related to the selected proxies. ES are the result of numerous ecosystem functions (Austen et al., 2011) making their assessment and quantification a comprehensive and challenging matter. This is further complicated given that the relationship between services, underlying ecosystem functions and biodiversity remains poorly understood (Barbier, 2007; Kremen, 2005). Furthermore, many marine species are highly mobile and may exhibit time dependent distribution patterns (Hattam et al., 2015). Ideally, this spatio-temporal dynamic is represented by the selected proxies. In addition to this, satellite data may underestimate in situ chl $a$ values in the study area (Peck et al., 2010). This bias is largest close to the coastline, but also along the Antarctic Peninsula, i.e. areas where tourism is most prominent. This may add to the weakening of the relationship between $\operatorname{chl} a$ and the ES.

The provisioning of ES is based on a complex, interdependent system of different ecosystem structures and processes. Consequently, ES provisioning often cannot be limited to a certain area or ecosystem component since this area or component is indirectly or directly interlinked with others. Thus, deriving ES hotspots directly from habitat information is quite simplifying and surely underestimates the spatial dimension of hotspots in the Weddell Sea study area. The ES provisioning is less straightforward (Maes et al., 2012). The hotspot area of genetic diversity surely exceeds the $1 \%$ ratio we assessed by surrounding "source" areas. These surrounding areas are slightly captured by the $30 \mathrm{~km}$ buffer we used for our sampling points. Also, capturing the ES genetic diversity by higher benthic taxa is again quite simplifying and further underestimates the genetic variation in the Weddell Sea study area. Further studies should aim at a distinctly higher taxonomic resolution and functional interconnection. Nevertheless, the results of this study offer valuable information on the biodiversity of the region within its limitations. 
Another aspect is the ongoing debate within the ES research community on the threshold for defining ES hotspots and coldspots. Egoh et al. (2008) mention the lack of published thresholds in the literature. Cut-off points for hotspots range from the top $10-30 \%$ of service provision (e.g. Anderson et al., 2009; Locatelli et al., 2014; Qiu and Turner, 2013).

Also, up till now, the classification approach of hotspots and coldspots is stated quite arbitrarily in the literature. Different thresholds lead to different results, and thus to different priorities for ES conservation planners. This is due to the fact that hotspots of ecosystem services - be it biodiversity (e.g. genetic diversity) or other ES - are often identified as geographic areas of effective ecosystem protection. Thus, biodiversity hotspots are a common measure to prioritise areas for biodiversity conservation (Egoh et al., 2008; Myers et al., 2000). Egoh et al. (2008) for example emphasized the danger of simply considering hotspot areas of ES as areas where payoff from safeguard measures would be greatest. Therefore, keeping the variation of thresholds in mind is very important when comparing different studies.

The strength of the study rests on the comprehensive use of data available for the study area, on the consistent agreement with other studies both with regard to methodology and results (e.g. Galparsoro et al., 2014; Grant et al., 2013; Locatelli et al., 2014; Lynch et al., 2009; Teschke et al., 2016a, 2016b, c) and on being a milestone in implementing the ES concept to the Antarctic Weddell Sea. Since the characterization of sets of ES has emerged only recently (Schröter et al., 2005), the current analyses may serve as a model example for mapping other marine regions. This is especially important in the light of a general lack of quantitative evidence available (UNEP, 2011). The results also open up the possibility to contribute to existing strategies, such as the planned Weddell Sea Marine Protected Area (WSMPA). This is particularly important since this study bridges the gap between the natural sciences and the social sciences. Further research on the topic in the study area may focus either on (i) the assessment of additional ES, (ii) more information on the relationships between the assessed ES (see Locatelli et al., 2014), or (iii) estimating their economic value. The latter is especially important to align economic forces with conservation (Daily et al., 2009) and to underpin that the large-scale losses of ES in the marine system also lead to negative economic effects (Costanza et al., 2014). A possible tool for the economic valuation of the services provided is the Integrated Valuation of Ecosystem Services and Tradeoffs tool (InVEST). The tool is an integrated approach to inform planners about the impacts of alternative resource management choices on the economy, human well- being, and the environment (Daily et al., 2009).

\section{Conclusion}

The analysed ES of the Weddell Sea are regionally or even globally important. Our results indicate that conservation efforts should consider larger spatial scales as the protection of a hotspot area of one service does not necessarily also enhance the provisioning of other services. The lack of data calls for cautiousness in relation to the largely undiscovered potential of the Weddell Sea ecosystem to provide benefits in the future. Looking ahead, due to progressing climate change effects, even more uncertainties arise, e.g. relating to the way climate processes affect the structure and dynamics of Southern Ocean ecosystems and how they will respond to these changes (Murphy et al., 2012; Teschke et al., 2016a). Management measures should integrate these uncertainties in their decision making which is a call for the protection of the Weddell Sea. This would clearly be in line with the precautionary philosophy of CCAMLR. Our study may be used within conservation planning tools, such as the decision support software Marxan (Ball et al., 2009). For example, a GIS layer regarding socioeconomic interest and their future projections, such as future changes of tourism activity, may be developed which tries to minimise an overlap with areas most important for protection. The consideration of ES, that are currently underrepresented in decision-making, could significantly enhance discussion between stakeholders concentrated on different human activities in the Weddell Sea.

\section{Acknowledgements}

This work is part of the master thesis of Michaela Deininger conducted at the University of Bayreuth in cooperation with the Alfred Wegener Institute, Helmholtz Centre for Polar and Marine Research (AWI). We would like to express our great appreciation to Dieter Gerdes, Heather Lynch and Ute Mühlenhardt-Siegel for providing data. This study would not have been possible without their contributions. Then, we are grateful to Hendrik Pehlke who provided us with continuous support with handling ArcGIS and R. The positive attitude between the scientists of this working group has made conducting this study an enjoyable endeavour.

\section{Appendix A}

See Figs. A1-A5. See Tables A1-A3.

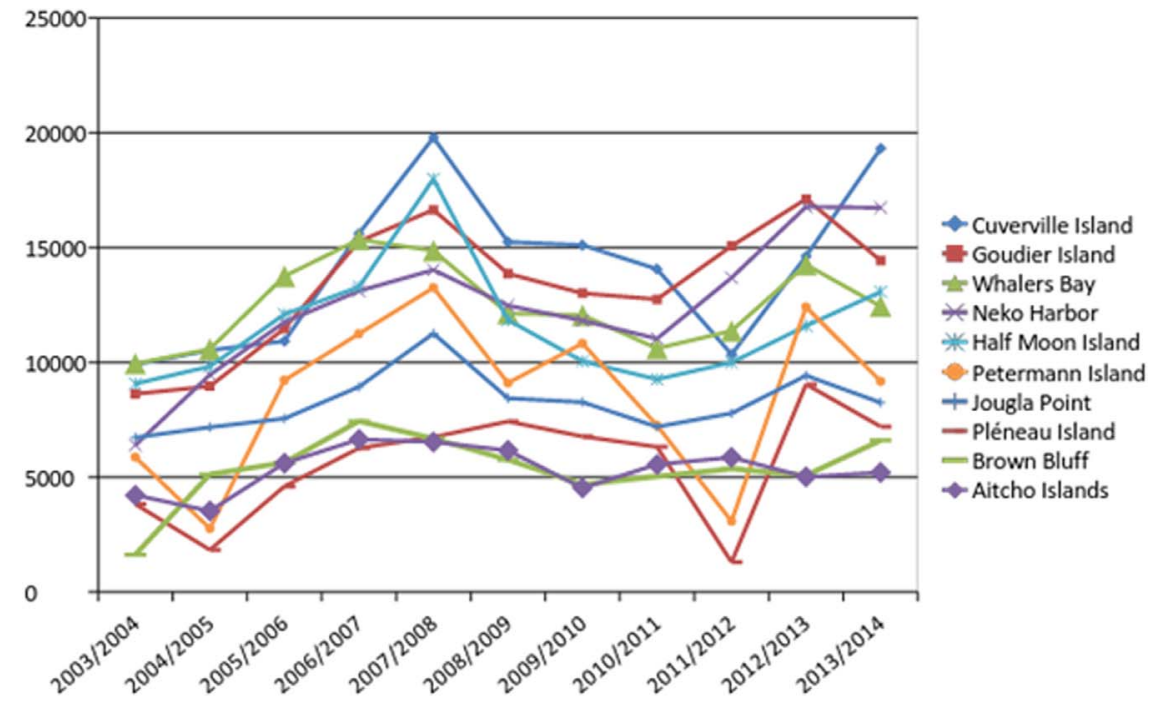

Fig. A.1. Number of tourists per season for the ten most visited destinations. Destinations are listed in decreasing order of mean tourist numbers. 


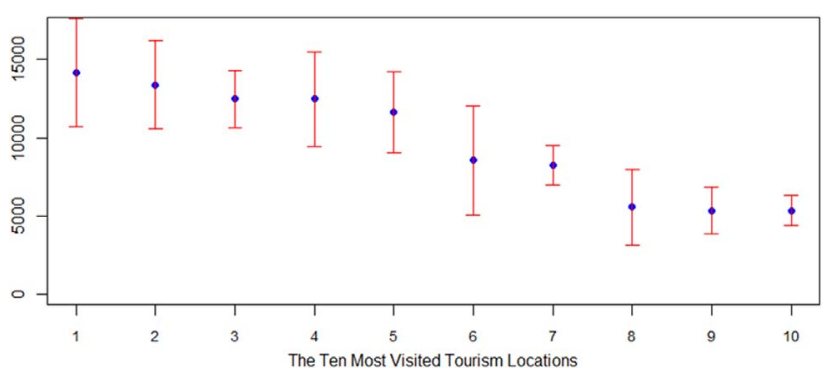

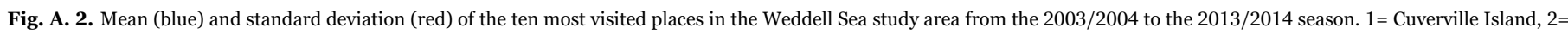

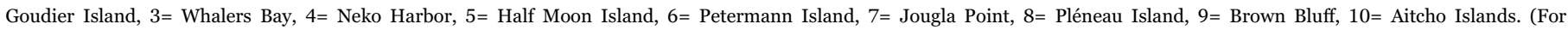
interpretation of the references to color in this figure legend, the reader is referred to the web version of this article.)

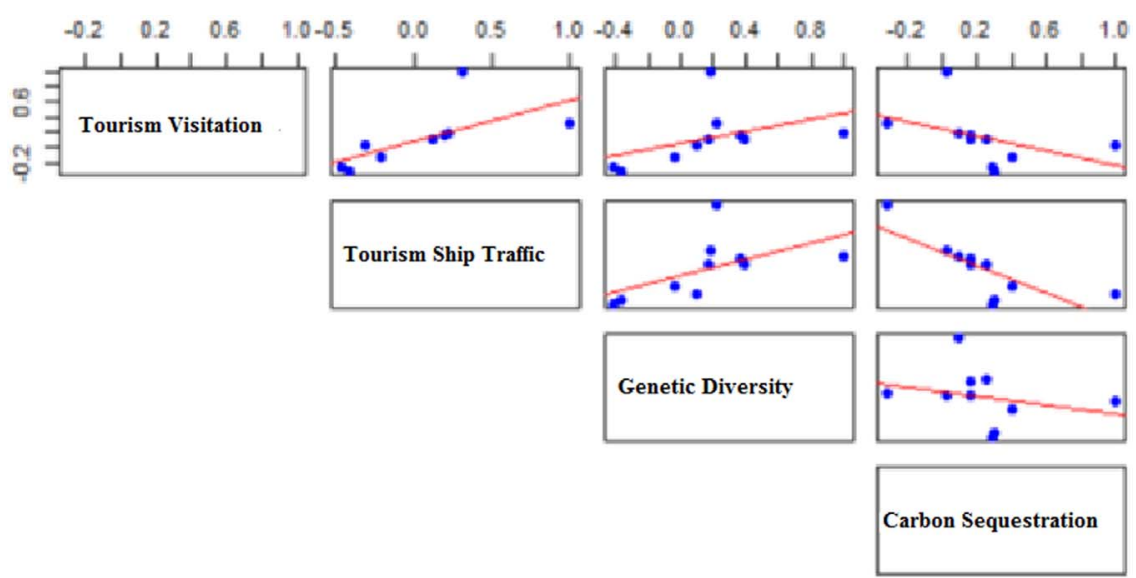

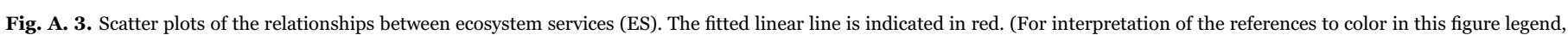
the reader is referred to the web version of this article.)

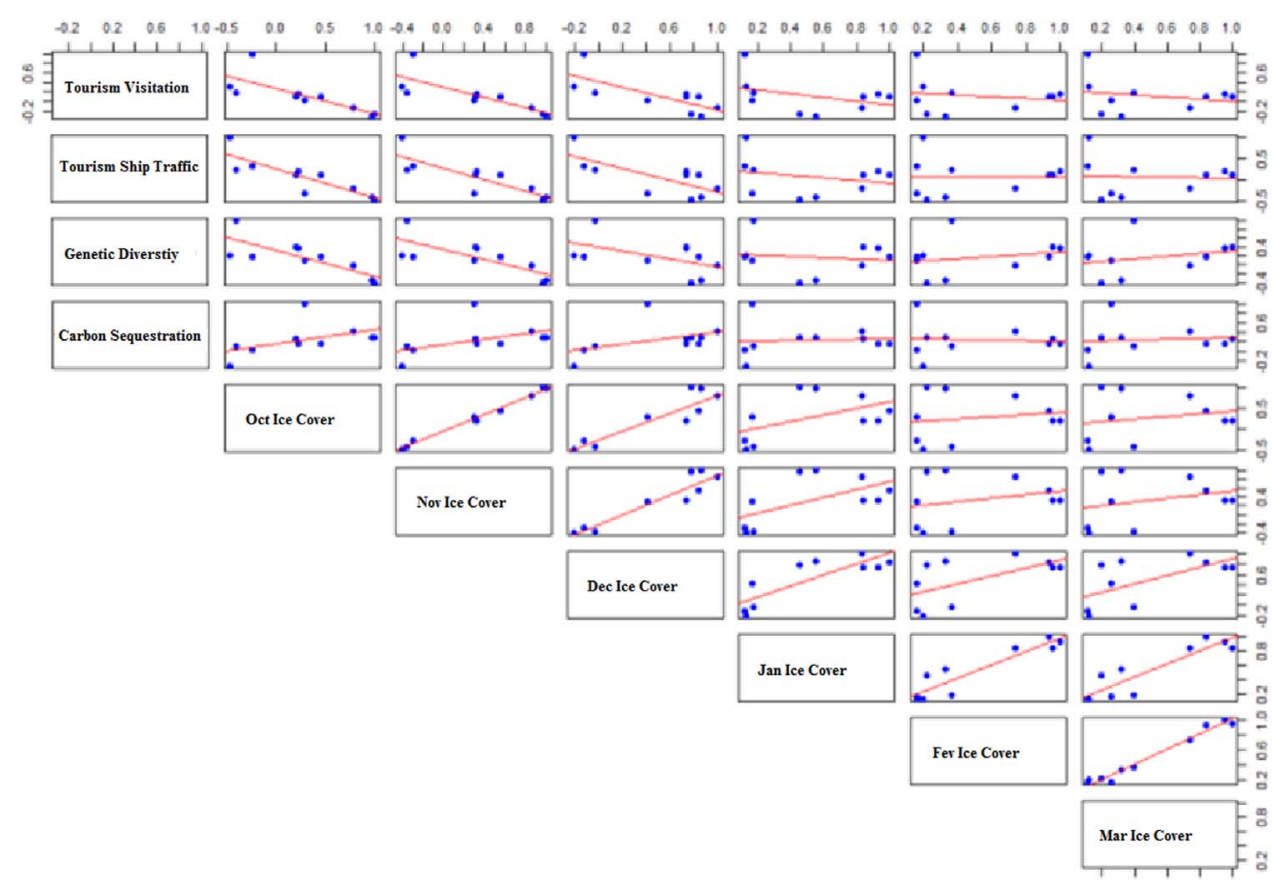

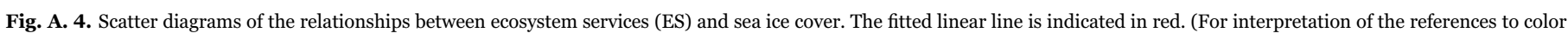
in this figure legend, the reader is referred to the web version of this article.) 


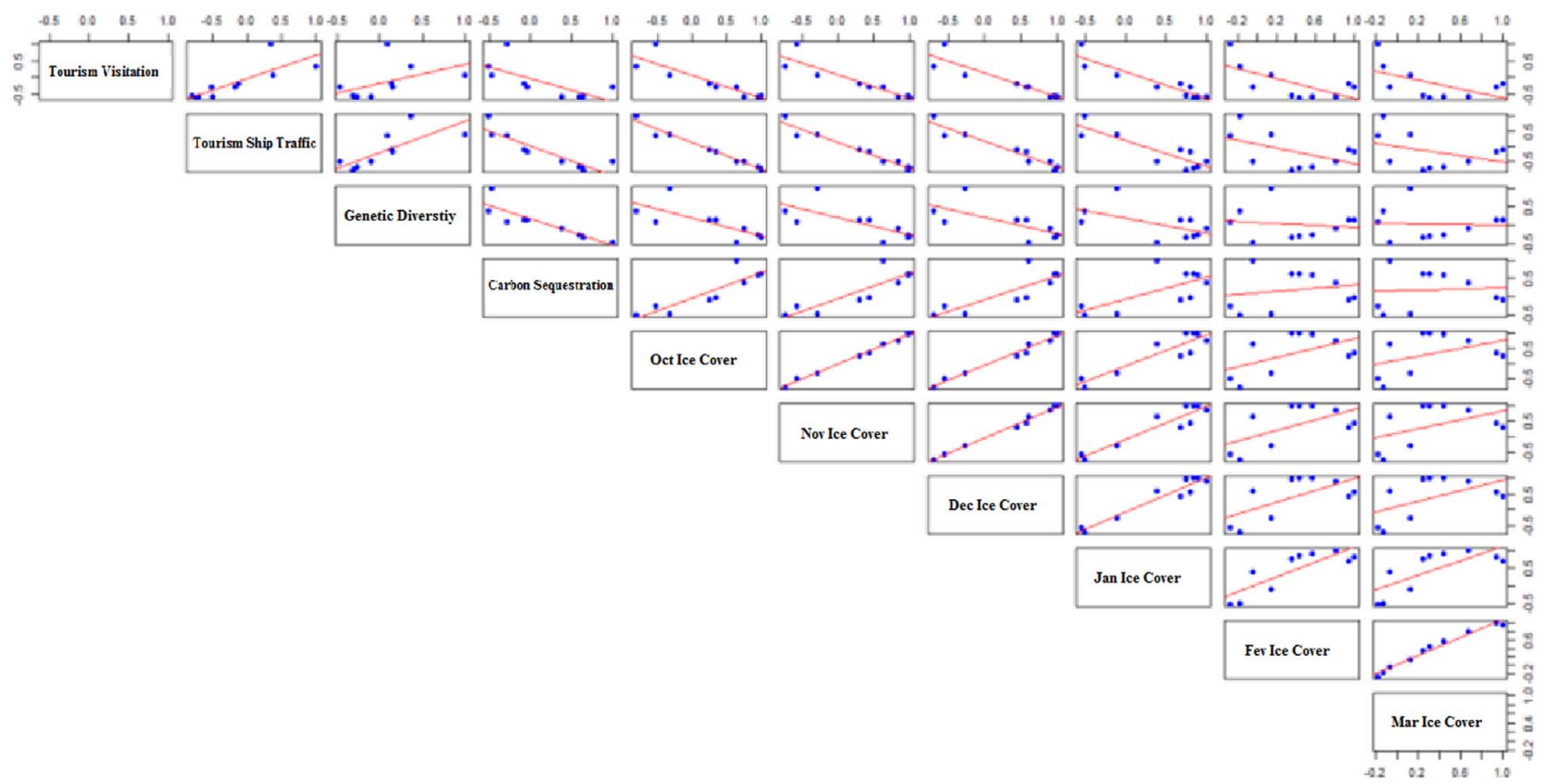

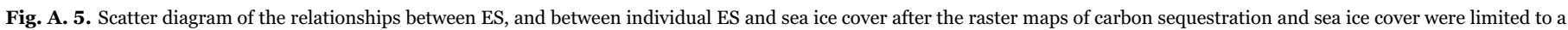

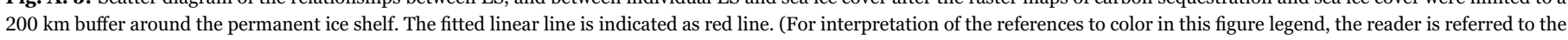
web version of this article.)

Table A.1

List of ecosystem services, and indicators for potential future tourism, respectively, and their proxies, data sets (incl. spatial and temporal resolution) and data sources.

\begin{tabular}{|c|c|c|c|c|c|}
\hline & Proxies & Sampling Design & Period & $\begin{array}{l}\text { Temporal } \\
\text { Resolution }\end{array}$ & Source (contact person, publication, web site) \\
\hline \multicolumn{6}{|l|}{ Ecosystem services } \\
\hline \multirow[t]{2}{*}{ Tourism } & Tourism visitation & & $2003-2014$ & annual & IAATO (2016) \\
\hline & Touristic ship traffic & & $2003-2008$ & annual & Lynch et al. (2009) \\
\hline Genetic diversity & Higher benthic taxa & $\begin{array}{l}\text { Various German Antarctic } \\
\text { expeditions (almost } 300 \\
\text { samples) }\end{array}$ & 1984-2011 & $\begin{array}{l}\text { Different time } \\
\text { intervals }\end{array}$ & $\begin{array}{l}\text { Partly unpublished data held by D. Gerdes (Alfred } \\
\text { Wegener Institute) and U. Mühlenhardt-Siegel } \\
\text { (German Center for Marine Biodiversity Research) }\end{array}$ \\
\hline $\begin{array}{l}\text { Carbon } \\
\quad \text { sequestration }\end{array}$ & Chl $a$ concentration & $0.83 \mathrm{~km} \times 0.83 \mathrm{~km}$ & $1997-2010$ & daily & $\begin{array}{l}\text { National Aeronautics and Space Administration } \\
\text { (NASA) Goddard Space Flight }\end{array}$ \\
\hline \multicolumn{6}{|c|}{ Indicators for potential future tourism } \\
\hline Sea ice cover & Sea ice concentration & $6.25 \mathrm{~km} \times 6.25 \mathrm{~km}$ & 2002-2011 & daily & $\begin{array}{l}\text { Kaleschke et al. (2001),Spreen et al. (2008), Institute } \\
\text { of Environmental Physics, University of Bremen: } \\
\text { http://www.iup.uni-bremen.de/seaice/amsr/ }\end{array}$ \\
\hline \multirow[t]{2}{*}{ Penguins } & $\begin{array}{l}\text { Adélie penguin } \\
\text { breeding colonies }\end{array}$ & $\begin{array}{l}\text { high resolution }(0.6 \mathrm{~m}) \text { satellite } \\
\text { imagery with spectral analysis }\end{array}$ & $2000 \mathrm{~s}$ & Snapshot in time & Lynch and LaRue (2014) \\
\hline & $\begin{array}{l}\text { Emperor penguin } \\
\text { breeding colonies }\end{array}$ & High resolution satellite imagery & 2009, 2012 & Snapshot in time & Fretwell et al. $(2012,2014)$ \\
\hline Mammals & Whales & $\begin{array}{l}14 \text { Polarstern cruises; } \\
\text { Opportunistic cetacean sightings }\end{array}$ & $2005-2013$ & Snapshot in time & $\begin{array}{l}\text { Burkhardt, 2009a-i; Burkhardt, 2011, 2012, 2013a, } \\
\text { 2013b, 2014;Bombosch et al. (2014) }\end{array}$ \\
\hline
\end{tabular}

Table A.2

Number of visitors per season and destination in the Weddell Sea study area (data according to IAATO); SD = standard deviation.

\begin{tabular}{|c|c|c|c|c|c|c|c|c|c|c|c|c|c|}
\hline Station & $03 / 04$ & $04 / 05$ & 05/06 & 06/07 & 07/08 & 08/09 & 09/10 & $10 / 11$ & $11 / 12$ & $12 / 13$ & $13 / 14$ & Mean & SD \\
\hline Cuverville Island & 9901 & 10523 & 10921 & 15607 & 19790 & 15244 & 15102 & 14061 & 10344 & 14621 & 19312 & 14129.64 & 3450.05 \\
\hline Goudier Island & 8621 & 8954 & 11472 & 15266 & 16640 & 13863 & 13004 & 12744 & 15062 & 17115 & 14438 & 13379.91 & 2806.07 \\
\hline Whalers Bay & 9941 & 10570 & 13749 & 15347 & 14858 & 12128 & 12054 & 10601 & 11368 & 14248 & 12444 & 12482.55 & 1837.91 \\
\hline Neko Harbor & 6387 & 9452 & 11749 & 13107 & 14023 & 12470 & 11816 & 11029 & 13681 & 16775 & 16733 & 12474.73 & 3002.09 \\
\hline Half Moon Island & 9064 & 9819 & 12086 & 13281 & 17984 & 11844 & 10040 & 9256 & 9990 & 11585 & 13070 & 11638.09 & 2571.87 \\
\hline Petermann Island & 5862 & 2756 & 9215 & 11241 & 13247 & 9098 & 10822 & 7248 & 3074 & 12406 & 9169 & 8558.00 & 3506.23 \\
\hline Jougla Point & 6721 & 7169 & 7547 & 8927 & 11252 & 8431 & 8260 & 7188 & 7776 & 9419 & 8242 & 8266.55 & 1273.58 \\
\hline Pléneau Island & 3818 & 1825 & 4592 & 6258 & 6739 & 7422 & 6767 & 6312 & 1290 & 9039 & 7198 & 5569.09 & 2414.68 \\
\hline Brown Bluff & 1621 & 5116 & 5629 & 7434 & 6674 & 5752 & 4675 & 5023 & 5357 & 5075 & 6592 & 5358.91 & 1499.19 \\
\hline
\end{tabular}


Table A.2 (continued)

\begin{tabular}{|c|c|c|c|c|c|c|c|c|c|c|c|c|c|}
\hline Station & $03 / 04$ & $04 / 05$ & $05 / 06$ & 06/07 & 07/08 & 08/09 & $09 / 10$ & $10 / 11$ & $11 / 12$ & $12 / 13$ & $13 / 14$ & Mean & SD \\
\hline Aitcho Islands & 4208 & 3520 & 5600 & 6639 & 6529 & 6156 & 4521 & 5551 & 5851 & 5002 & 5200 & 5343.36 & 976.65 \\
\hline Danco Island & 702 & 1910 & 2762 & 3655 & 3634 & 2959 & 4040 & 3016 & 4700 & 8198 & 6981 & 3868.82 & 2142.30 \\
\hline Skontorp Cove & 2007 & 1757 & 2800 & 5602 & 5613 & 4635 & 3752 & 4634 & 316 & 5311 & 5335 & 3796.55 & 1819.21 \\
\hline Paulet Island & 1365 & 3611 & 4507 & 5561 & 4978 & 7814 & 2529 & 3614 & 5414 & 118 & 615 & 3647.82 & 2340.24 \\
\hline Telefon Bay & 1351 & 1510 & 2184 & 3252 & 3068 & 3049 & 2269 & 2862 & 3622 & 3800 & 4510 & 2861.55 & 965.67 \\
\hline Point Wild & 2056 & 2556 & 4457 & 3489 & 3087 & 3363 & 2699 & 1966 & 559 & 1965 & 3769 & 2724.18 & 1073.94 \\
\hline Hannah Point & 4246 & 3873 & 5601 & 94 & 2039 & 2678 & 1681 & 1689 & 2716 & 2209 & 2188 & 2637.64 & 1480.93 \\
\hline Melchior Islands & 2111 & 1684 & 2694 & 3800 & 5258 & 2847 & 3263 & 3657 & 144 & 1788 & 1738 & 2634.91 & 1364.94 \\
\hline Yankee Harbor & 3026 & 1872 & 2521 & 3273 & 3987 & 2072 & 1863 & 1704 & 1081 & 2238 & 3736 & 2488.45 & 911.66 \\
\hline Baily Head & 1843 & 1294 & 3504 & 2279 & 1937 & 1989 & 1886 & 1354 & 1533 & 2332 & 3206 & 2105.18 & 704.16 \\
\hline Pendulum Cove & 2014 & 2389 & 4093 & 4021 & 1893 & 2337 & 1873 & 1109 & 678 & 809 & 533 & 1977.18 & 1219.19 \\
\hline Devil Island & 277 & 1992 & 2370 & 2809 & 925 & 2852 & 2056 & 1268 & 1314 & 86 & 273 & 1474.73 & 1013.02 \\
\hline Yalour Islands & 1357 & 585 & 1361 & 2564 & 1235 & 1536 & 1191 & 920 & 328 & 1670 & 2688 & 1403.18 & 722.72 \\
\hline Gibbs Island & 156 & 0 & 128 & 0 & 2157 & 2575 & 5841 & 3791 & 69 & 149 & 376 & 1385.64 & 1971.33 \\
\hline Penguin Island & 2311 & 1419 & 1724 & 1480 & 2189 & 1737 & 1288 & 93 & 651 & 943 & 516 & 1304.64 & 696.41 \\
\hline Enterprise Island & 331 & 1649 & 1454 & 1528 & 1843 & 1317 & 636 & 953 & 263 & 1762 & 2347 & 1280.27 & 661.34 \\
\hline Argentine Islands & 1627 & 930 & 1111 & 1822 & 1450 & 1544 & 1118 & 296 & 467 & 475 & 1190 & 1093.64 & 509.25 \\
\hline Detaille Island & 731 & 0 & 155 & 754 & 1071 & 1402 & 1512 & 1587 & 0 & 2371 & 1465 & 1004.36 & 756.04 \\
\hline Gourdin Island & 242 & 1009 & 575 & 506 & 548 & 1261 & 996 & 236 & 494 & 1222 & 2318 & 855.18 & 605.57 \\
\hline Portal Point & 703 & 551 & 690 & 609 & 598 & 893 & 425 & 707 & 878 & 1813 & 1501 & 851.64 & 425.80 \\
\hline Cape Lookout & 494 & 1425 & 1083 & 656 & 376 & 686 & 1016 & 320 & 325 & 491 & 1119 & 726.45 & 376.60 \\
\hline Torgersen Island & 657 & 738 & 763 & 613 & 786 & 228 & 959 & 736 & 336 & 853 & 416 & 644.09 & 227.06 \\
\hline Fish Islands & 264 & 111 & 703 & 514 & 1133 & 1138 & 1270 & 751 & 195 & 259 & 617 & 632.27 & 410.41 \\
\hline Astrolabe Island & 439 & 368 & 694 & 353 & 594 & 806 & 301 & 1678 & 192 & 1043 & 220 & 608.00 & 441.58 \\
\hline Useful Island & 0 & 335 & 146 & 805 & 751 & 1083 & 718 & 1597 & 55 & 412 & 549 & 586.45 & 477.01 \\
\hline Hydrurga Rocks & 495 & 328 & 424 & 270 & 442 & 509 & 616 & 83 & 689 & 1168 & 949 & 543.00 & 306.97 \\
\hline Orne Islands & 172 & 661 & 679 & 697 & 1010 & 451 & 140 & 1317 & 177 & 268 & 149 & 520.09 & 392.54 \\
\hline Horseshoe Island & 207 & 323 & 0 & 261 & 337 & 1020 & 981 & 556 & 174 & 465 & 812 & 466.91 & 338.90 \\
\hline Prospect Point & 593 & 0 & 265 & 526 & 738 & 591 & 285 & 960 & 131 & 600 & 168 & 441.55 & 292.59 \\
\hline Stonington Island & 92 & 98 & 0 & 330 & 450 & 1153 & 1027 & 582 & 0 & 339 & 756 & 438.82 & 402.57 \\
\hline Robert Point & 462 & 129 & 302 & 1074 & 380 & 270 & 319 & 120 & 153 & 344 & 748 & 391.00 & 287.71 \\
\hline Turret Point & 105 & 253 & 414 & 141 & 994 & 273 & 96 & 326 & 196 & 741 & 713 & 386.55 & 299.44 \\
\hline Shingle Cove & 881 & 307 & 282 & 1014 & 92 & 346 & 431 & 109 & 137 & 0 & 0 & 327.18 & 338.41 \\
\hline Georges Point & 624 & 0 & 0 & 694 & 153 & 365 & 78 & 13 & 165 & 464 & 546 & 282.00 & 264.53 \\
\hline Hovgaard Island & 153 & 7 & 124 & 141 & 183 & 96 & 233 & 1431 & 191 & 194 & 242 & 272.27 & 389.96 \\
\hline Spigot Peak & 255 & 805 & 512 & 327 & 131 & 195 & 239 & 47 & 222 & 138 & 21 & 262.91 & 224.74 \\
\hline Snow Hill Island & 58 & 1150 & 520 & 0 & 276 & 284 & 0 & 16 & 375 & 0 & 89 & 251.64 & 347.18 \\
\hline Rosamel Island & 68 & 681 & 0 & 0 & 74 & 0 & 108 & 1327 & 0 & 143 & 91 & 226.55 & 413.60 \\
\hline Damoy Point & 642 & 1292 & 0 & 0 & 0 & 0 & 0 & 0 & 0 & 0 & 0 & 175.82 & 417.30 \\
\hline Ardley Island & 0 & 0 & 108 & 140 & 267 & 214 & 273 & 217 & 362 & 120 & 2 & 154.82 & 123.19 \\
\hline Wauwermans Islands & 0 & 0 & 0 & 3 & 65 & 24 & 75 & 1345 & 67 & 0 & 8 & 144.27 & 399.38 \\
\hline Waddington Bay & 229 & 0 & 100 & 220 & 430 & 117 & 93 & 12 & 92 & 116 & 89 & 136.18 & 120.03 \\
\hline Heroina Island & 0 & 93 & 212 & 243 & 0 & 272 & 76 & 68 & 393 & 0 & 0 & 123.36 & 135.67 \\
\hline Union Glacier & 0 & 0 & 0 & 0 & 0 & 0 & 0 & 275 & 0 & 682 & 263 & 110.91 & 217.86 \\
\hline Bongrain Point & 0 & 0 & 0 & 0 & 110 & 175 & 0 & 180 & 127 & 226 & 396 & 110.36 & 128.52 \\
\hline Dorian Bay & 417 & 694 & 0 & 0 & 0 & 0 & 0 & 0 & 0 & 0 & 0 & 101.00 & 233.09 \\
\hline Patriot Hills & 0 & 188 & 0 & 200 & 253 & 282 & 161 & 0 & 0 & 0 & 0 & 98.55 & 117.46 \\
\hline Seymour Island & 0 & 146 & 30 & 171 & 228 & 42 & 12 & 69 & 107 & 0 & 146 & 86.45 & 77.88 \\
\hline Penguin Point & 0 & 0 & 126 & 172 & 181 & 0 & 0 & 49 & 384 & 0 & 0 & 82.91 & 123.48 \\
\hline D'Urville Monument & 0 & 0 & 63 & 0 & 513 & 0 & 0 & 237 & 0 & 0 & 0 & 73.91 & 162.24 \\
\hline Intercurrence Island & 0 & 42 & 0 & 51 & 668 & 0 & 0 & 0 & 0 & 0 & 0 & 69.18 & 199.48 \\
\hline Cape Valentine & 0 & 0 & 199 & 70 & 0 & 0 & 335 & 0 & 0 & 0 & 111 & 65.00 & 110.71 \\
\hline Christiania Islands & 87 & 53 & 0 & 79 & 4 & 53 & 50 & 52 & 45 & 240 & 39 & 63.82 & 64.03 \\
\hline Crystal Hill & 93 & 255 & 90 & 49 & 0 & 0 & 0 & 0 & 197 & 0 & 0 & 62.18 & 89.69 \\
\hline Duthiers Point & 0 & 0 & 234 & 0 & 411 & 0 & 0 & 0 & 5 & 9 & 6 & 60.45 & 135.51 \\
\hline View Point & 0 & 214 & 84 & 0 & 0 & 45 & 0 & 138 & 0 & 86 & 0 & 51.55 & 72.17 \\
\hline Cape Tuxen & 82 & 5 & 10 & 0 & 5 & 269 & 8 & 24 & 0 & 110 & 14 & 47.91 & 81.81 \\
\hline Madder Cliffs & 94 & 317 & 0 & 0 & 0 & 0 & 0 & 0 & 0 & 0 & 0 & 37.36 & 96.94 \\
\hline Berthelot Islands & 0 & 0 & 0 & 366 & 0 & 0 & 0 & 0 & 0 & 36 & 0 & 36.55 & 109.80 \\
\hline Novolazarevskaya (Novo) station & 0 & 0 & 0 & 0 & 0 & 0 & 52 & 88 & 0 & 127 & 97 & 33.09 & 48.93 \\
\hline Girard Bay & 0 & 5 & 0 & 0 & 9 & 44 & 53 & 228 & 0 & 10 & 0 & 31.73 & 67.72 \\
\hline Charcot, Port & 323 & 0 & 0 & 0 & 0 & 0 & 0 & 0 & 0 & 0 & 0 & 29.36 & 97.39 \\
\hline Atka Bay Rookery (Atka Iceport) & 0 & 206 & 0 & 0 & 0 & 0 & 0 & 101 & 0 & 0 & 0 & 27.91 & 66.38 \\
\hline Danger Islands & 43 & 0 & 143 & 42 & 0 & 0 & 0 & 0 & 0 & 35 & 0 & 23.91 & 43.59 \\
\hline Camp Point & 108 & 5 & 0 & 0 & 143 & 0 & 0 & 0 & 0 & 0 & 0 & 23.27 & 51.17 \\
\hline Fildes Peninsula & 133 & 0 & 0 & 0 & 0 & 0 & 0 & 0 & 0 & 67 & 19 & 19.91 & 42.64 \\
\hline Blaiklock Island & 0 & 0 & 0 & 0 & 4 & 0 & 72 & 64 & 77 & 0 & 0 & 19.73 & 33.08 \\
\hline Jonassen Island & 0 & 0 & 0 & 0 & 0 & 0 & 57 & 106 & 0 & 0 & 0 & 14.82 & 34.74 \\
\hline Mount Demaria & 17 & 0 & 19 & 19 & 13 & 9 & 22 & 0 & 1 & 25 & 17 & 12.91 & 9.09 \\
\hline Pitt Islands & 0 & 0 & 28 & 8 & 8 & 23 & 18 & 0 & 5 & 29 & 22 & 12.82 & 11.44 \\
\hline Alcock Island & 0 & 96 & 0 & 34 & 0 & 0 & 0 & 0 & 0 & 0 & 0 & 11.82 & 29.72 \\
\hline Cape Kinnes & 0 & 79 & 0 & 0 & 0 & 0 & 0 & 0 & 0 & 0 & 48 & 11.55 & 26.61 \\
\hline Murray Island & 0 & 0 & 0 & 2 & 92 & 11 & 0 & 0 & 0 & 5 & 10 & 10.91 & 27.21 \\
\hline Suárez Glacier & 96 & 0 & 0 & 0 & 0 & 0 & 0 & 0 & 0 & 0 & 0 & 8.73 & 28.95 \\
\hline Mount Mill & 0 & 0 & 3 & 9 & 24 & 9 & 21 & 2 & 7 & 0 & 7 & 7.45 & 8.24 \\
\hline
\end{tabular}


Table A.2 (continued)

\begin{tabular}{|c|c|c|c|c|c|c|c|c|c|c|c|c|c|}
\hline Station & $03 / 04$ & 04/05 & $05 / 06$ & 06/07 & 07/08 & 08/09 & $09 / 10$ & $10 / 11$ & $11 / 12$ & $12 / 13$ & $13 / 14$ & Mean & SD \\
\hline Heywood Island & 0 & 0 & 0 & 0 & 0 & 0 & 0 & 0 & 80 & 0 & 0 & 7.27 & 24.12 \\
\hline Barcroft Islands & 0 & 50 & 0 & 0 & 0 & 0 & 0 & 0 & 0 & 6 & 0 & 5.09 & 15.00 \\
\hline Palaver Point & 0 & 0 & 0 & 0 & 0 & 0 & 0 & 0 & 5 & 10 & 29 & 4.00 & 8.89 \\
\hline Duthoit Point & 0 & 33 & 0 & 0 & 0 & 0 & 0 & 0 & 0 & 0 & 0 & 3.00 & 9.95 \\
\hline Bennett Islands & 0 & 0 & 0 & 0 & 0 & 12 & 0 & 0 & 5 & 0 & 0 & 1.55 & 3.78 \\
\hline Wiggins Glacier & 0 & 0 & 0 & 0 & 0 & 0 & 0 & 0 & 0 & 16 & 0 & 1.45 & 4.82 \\
\hline Challenger Island & 0 & 7 & 0 & 0 & 0 & 0 & 0 & 0 & 0 & 0 & 8 & 1.36 & 3.04 \\
\hline Cape Evensen & 0 & 0 & 0 & 6 & 0 & 0 & 0 & 0 & 0 & 3 & 0 & 0.82 & 1.94 \\
\hline Spring Point & 0 & 0 & 0 & 0 & 0 & 0 & 0 & 0 & 0 & 0 & 6 & 0.55 & 1.81 \\
\hline Macaroni Point & 0 & 0 & 2 & 0 & 0 & 0 & 0 & 0 & 0 & 0 & 0 & 0.18 & 0.60 \\
\hline
\end{tabular}

Table A.3

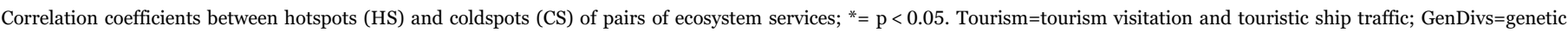
diversity; CarbSeq=carbon sequestration .

\begin{tabular}{|c|c|c|c|c|c|c|}
\hline & Tourism HS & GenDiv HS & CarbSeq HS & Tourism CS & GenDiv CS & CarbSeq CS \\
\hline Tourism HS & 1.00 & -0.19 & -0.25 & -0.75 & $-0.03^{*}$ & 0.09 \\
\hline GenDiv HS & -0.19 & 1.00 & 0.06 & 0.22 & -0.37 & 0.10 \\
\hline CarbSeq HS & -0.25 & 0.06 & 1.00 & 0.33 & -0.09 & -0.28 \\
\hline Tourism CS & -0.75 & 0.22 & 0.33 & 1.00 & $0.04^{*}$ & -0.25 \\
\hline GenDiv CS & $-0.03^{*}$ & -0.37 & -0.09 & $0.04^{*}$ & 1.00 & -0.13 \\
\hline CarbSeq CS & 0.09 & 0.10 & -0.28 & -0.25 & -0.13 & 1.00 \\
\hline
\end{tabular}

\section{References}

Anderson, B.J., Armsworth, P.R., Eigenbrod, F., Thomas, C.D., Gillings, S., Heinemeyer, A., Roy, D.B., Gaston, K.J., 2009. Spatial covariance between biodiversity and other ecosystem service priorities. J. Appl. Ecol. 46, 888-896. http://dx.doi.org/10.1111/ j.1365-2664.2009.01666.x.

Antarpply Expeditions, 2016. Weddell Sea Quest. 〈http://www.antarpply.com/en/ availability (accessed 20.10.16)

AOA, Antarctic Ocean Alliance, 2013. Antarctic Ocean Legacy: Towards Protection of the Weddell Sea Region. Available online: 〈http://www.antarcticocean.org/wp-content/ uploads/2013/03/Weddell-Sea-Report-FINAL-ENGLISH.pdf $\rangle$ (accessed 20.10.16).

ATS, Antarctic Treaty System, 1991. Protocol on Environmental Protection to the Antarctic Treaty.〈http://www.ats.aq/documents/recatt/Att006_e.pdf (accessed 20. 10.16)

Austen, M.C., Malcolm, S.J., Frost, M., Hattam, C., Mangi, S., Stentford, G., Benjamins, S., Burrows, M., Butenschön, M., Duck, C., Johns, D., Merino, G., Mieszkowska, N., Miles, A., Mitchell, I., Smyth, T., 2011. Marine: The UK National Ecosystem Assessment Technical Report (UK NEA, 2011). Publishers: UNEP-WCMC

Ball, I.R., Possingham, H.P., Watts, M., 2009. Marxan and relatives: software for spatial conservation prioritisation. In: Moilanen, A., Wilson, K.A., Possingham, H.P. (Eds.), Spatial Conservation Prioritisation: Quantitative Methods and Computational Tools. Oxford University Press, Oxford, UK, 185-195.

Barbier, E.B., 2007. Valuing ecosystem services as productive inputs. Econ. Policy 22, 177-229. http://dx.doi.org/10.1111/j.1468-0327.2007.00174.x.

Barbier, E.B., 2012. Progress and challenges in valuing coastal and marine ecosystem services. Rev. Environ. Econ. Policy 6, 1-19. http://dx.doi.org/10.1093/reep/ rer017.

Bombosch, A., Zitterbart, D.P., van Opzeeland, I., Frickenhaus, S., Burkhardt, E., Wisz, M.S., Boebel, O., 2014. Predictive habitat modelling of humpback (Megaptera novaeangliae) and Antarctic minke (Balaenoptera bonaerensis) whales in the Southern Southern Ocean as a planning tool for seismic surveys. Deep-Sea Res. I 91, 101-114. http://dx.doi.org/10.1016/j.dsr.2014.05.017.

Boyce, D.G., Lewis, M.R., Worm, B., 2010. Global phytoplankton decline over the past century. Nature 466, 591-596. http://dx.doi.org/10.1038/nature0926.

Brandt, A., Brix, S., Brökeland, W., Choudhury, M., Kaiser, S., Malyutina, M., 2007. Deep-sea isopod biodiversity, abundance and endemism in the Atlantic sector of the Southern Ocean - results from the ANDEEP I - III expeditions. Deep-Sea Res. II 54, 1760-1775.

Brey, T., Klages, M., Dahm, C., Gorny, M., Gutt, J., Hain, S., Stiller, M., Arntz, W., Wägele, J.W., Zimmermann, A., 1994. Antarctic benthic diversity. Nature, 368. http://dx.doi.org/10.1038/368297a0.

Burkhard, B., Kroll, F., Nedkovb, S., Müller, F., 2012. Mapping ecosystem service supply, demand and budgets. Ecol. Indic. 21, 17-29. http://dx.doi.org/10.1016/ j.ecolind.2011.06.019.

Burkhardt, E., 2009a-i. Whale sightings during POLARSTERN cruise ANT-XXII/3. Alfred Wegener Institute, Helmholtz Center for Polar and Marine Research, Bremerhaven. Doi: 10.1594/PANGAEA.729027; Doi: 10.1594/PANGAEA.729030; Doi: 10.1594/PANGAEA.729034; Doi: 10.1594/PANGAEA.729035; Doi: 10.1594/ PANGAEA.729036; Doi: 10.1594/PANGAEA.729037; Doi: 10.1594/PANGAEA. 729040; Doi: 10.1594/PANGAEA.729041; Doi: 10.1594/PANGAEA.728270 (accessed 04.12.15).

Burkhardt, E., 2011. Whale sightings during POLARSTERN cruise ANT-XXVII/2. Alfred Wegener Institute, Helmholtz Center for Polar and Marine Research, Bremerhaven. http://dx.doi.org/10.1594/PANGAEA.760340.

Burkhardt, E., 2012. Whale sightings during POLARSTERN cruise ANT-XXVII/3 AlfredWegener Institute, Helmholtz Center for Polar and Marine Research, Bremerhaven. http://dx.doi.org/10.1594/PANGAEA.783806.

Burkhardt, E., 2013a. Whale sightings during POLARSTERN cruise ANT-XXVIII/2 Alfred Wegener Institute, Helmholtz Center for Polar and Marine Research, Bremerhaven. http://dx.doi.org/10.1594/PANGAEA.819861.

Burkhardt, E., 2013b. Whale sightings during POLARSTERN cruise ANT-XXIX/2. Alfred Wegener Institute, Helmholtz Center for Polar and Marine Research, Bremerhaven. http://dx.doi.org/10.1594/PANGAEA.819866.

Burkhardt, E., 2014. Whale sightings during POLARSTERN cruise ANT-XXIX/3. Alfred Wegener Institute, Helmholtz Center for Polar and Marine Research, Bremerhaven. http://dx.doi.org/10.1594/PANGAEA.840382.

Burrough, P.A., McDonnell, R.A., 1998. Principals of geographical information systems. Oxford University Press.

Carpenter, S.R., DeFries, R., Dietz, T., Mooney, H.A., Polasky, S., Reid, R.V., Scholes, R.J., 2006. Millennium ecosystem assessment: research needs. Science 314 (5797), 257-258. http://dx.doi.org/10.1126/science.1131946.

Catarci, C., 2004. World markets and industry of selected commercially exploited aquatic species with an international conservation profile. FAO Fisheries Circular, 990. Food and Agriculture Organization (FAO), Rome.

CBD, Convention on Biological Diversity, 2010. The concept of genetic resources in the convention on biological diversity and how it relates to a functional international regime on access and benefit-sharing. 〈https://www.cbd.int/doc/meetings/abs/ abswg-09/information/abswg-09-inf-01-en.pdf) (accessed 20.10.16).

CBD, Convention on Biological Diversity, 2012. Ecologically or Biologically Significant Marine Areas (EBSAs). 〈http://www.cbd.int/marine/doc/ebsa-brochure-2012-en. pdf $\rangle$ (accessed 20.10.16)

CBD, Convention on Biological Diversity, 2015. Infrastructure and industrialization. 〈https://www.cbd.int/idb/2015/goals/sdg9/〉 (accessed 20.10.16).

CCAMLR, Commission for the Conservation of Antarctic Marine Living Resources, 2015. Report of the Thirty-In: Proceedings of the fourth Meeting of the Commission (Hobart, Australia, 19 to 30 October 2015), 209 pp.

Clarke, A., Johnston, N.M., 2003. Antarctic marine benthic diversity. Oceanogr. Mar. Biol. 41, 47-114.

Costanza, R., 1999. The ecological, economic, and social importance of the oceans. Ecol. Econ. 31, 199-213. http://dx.doi.org/10.1016/j.biocon.2007.12.020.

Costanza, R., de Groot, R.S. de, Sutton, P., Ploeg, S., van der, Anderson, S.J., Kubiszewski, I., Farber, S., Turner, R.K., 2014. Chang. Glob. Value Ecosyst. Serv. Glob. Environ. Change 26, 152-158. http://dx.doi.org/10.1016/ j.gloenvcha.2014.04.002.

Costanza, R., D’arge, R., De Groot, R., Farber, S., Grasso, M., Hannon, B., Limburg, K., Naeem, S., O’neill, R.V., Paruelo, J., Raskin, R.G., Sutton, P., Van Den Belt, M., 1997. The value of the world's ecosystem services and natural capital. Nature 387, 253-260.

Croll, D.A., Marinovic, B., Benson, S., Chavez, F.P., Black, N., Ternullo, R., Tershy, B.R., 2005. From wind to whales: trophic links in a coastal upwelling system. Mar. Ecol. Prog. Ser. 289, 117-130. 
Daily, G., Kareiva, P., Tillis, H., Ricketts, T., Polasky, S., 2011. Mainstreaming natural capital into decisions. In: Kareiva, P.M. (Ed.), Natural capital. Theory \& practice of mapping ecosystem services. Oxford University Press, Oxford, 3-14.

Daily, G.C., Matson, P.A., 2008. Ecosystem services: from theory to implementation. Proc. Natl. Acad. Sci. 105 (28), 9455-9456, (Doi: 10.1073pnas.0804960105).

Daily, G.C., Polasky, S., Goldstein, J., Kareiva, P.M., Mooney, H.A., Pejchar, L., Ricketts, T.H., Salzman, J., Shallenberger, R., 2009. Ecosystem services in decision making: time to deliver. Front. Ecol. Environ. 7 (1), 21-28. http://dx.doi.org/10.1890/ 080025 .

de Groot, R.S., Wilson, M., Boumans, R., 2002. A typology for the description, classification and valuation of ecosystem functions, goods and services. Ecological Economics 41 (3), 393-408.

Douglass, L.L., Turner, J., Grantham, H.S., Kaiser, S., Constable, A., Nicoll, R., Raymond, B., Post, A., Brandt, A., Beaver, D., 2014. A hierarchical classification of benthic biodiversity and assessment of protected areas in the Southern Ocean. PLoS ONE 9, e100551. http://dx.doi.org/10.1371/journal.pone.0100551.

Egoh, B., Reyers, B., Rouget, M., Richardson, D.M., van Jaarsveld, A.S., 2008. Mapping ecosystem services for planning and management. Agric. Ecosyst. Environ. 127, 135-140. http://dx.doi.org/10.1016/j.agee.2008.03.013.

Egoh, B., Drakou, E.G., Dunbar, M.B., Maes, J., Willemen, L., 2012. Indicators for Mapping Ecosystem Services: a Review. Joint Research Centre Scientific and Policy Reports, Luxembourg.

ESRI, 2011. ArcGIS Desktop: release 10. Environmental Systems Research Institute Redlands, CA.

FAO, Food and Agriculture Organization, 2016. Genetic resources. 〈http://www.fao.org/ genetic-resources/en/> (accessed 20.10.16).

Fisher, B., Turner, R.K., Morling, P., 2009. Defining and classifying ecosystem services for decision making. Ecol. Econ. 68 (3), 643-653. http://dx.doi.org/10.1016/ j.ecolecon.2008.09.014.

Flores, H., 2009. Frozen desert alive. The role of sea ice for pelagic macrofauna and its predators: implications for the Antarctic pack-ice food web. Available online: 〈http://epic.awi.de/30609/1/Flores_FrozenDesertAlive_std.pdf) (accessed 20.10. 16).

Foldvik, A., Gammelsrød, T., Østerhus, S., Fahrbach, E., Rohardt, G., Schröder, M., Nicholls, K.W., Padman, L., Woodgate, R.A., 2004. Ice shelf water overflow and bottom water formation in the southern Weddell Sea. J. Geophys. Res. 109 (C02015). http://dx.doi.org/10.1029/2003JC002008.

Fretwell, P.T., Trathan, P.N., Wienecke, B., Kooyman, G.L., 2014. Emperor penguins breeding on iceshelves. PLoS One 9 (1), e85285. http://dx.doi.org/10.1371/ journal.pone.0085285.

Fretwell, P.T., LaRue, M.A., Morin, P., Kooyman, G.L., Wienecke, B., Ratcliffe, N., Fox, A.J., Fleming, A.H., Porter, C., Trathan, P.N., 2012. An emperor penguin population estimate: thethe first global, synoptic survey of a species from space. PLoS One 7 (4), e33751. http://dx.doi.org/10.1371/journal.pone.0033751.

Galparsoro, I., Borja, A., Uyarra, M.C., 2014. Mapping ecosystem services provided by benthic habitats in the European North Atlantic Ocean. Front. Mar. Sci.. http:// dx.doi.org/10.3389/fmars.2014.00023

Gerdes, D., Klages, M., Arntz, W.E., Herman, R.L., Galéron, J., Hain, S., 1992. Quantitative investigations on macrobenthos communities of the southeastern Weddell Sea shelf based on multibox corer samples. Polar Biol. 12, 291-301. http:// dx.doi.org/10.1007/BF00238272.

Ghermandi, A., Nunes, P.A.L.D., Portela, R., Rao, N., Teelucksingh, S.S., 2012. Recreational, cultural and aesthetic services from estuarine and coastal ecosystems. (Series eds. Wolanski, E., and McLusky, D.)In: van den Belt, M., Costanza, R. (Eds.), Ecological Economics of Estuaries and Coasts, Vol. 12, Chapter 11, Treatise on estuarine and coastal science. Academic Press, Waltham, MA, 217-237.

Gill, P.C., Thiele, D., 1997. A winter sighting of killer whales (Orcinus orca) in Antarctic sea ice. Polar Biol. 17, 401-404.

Gimona, A., van der Horst, D., 2007. Mapping hotspots of multiple landscape functions: a case study on farmland afforestation in Scotland. Landsc. Ecol. 22 (8), 1255-1264. http://dx.doi.org/10.1007/s10980-007-9105-7.

Gjerde, K.M., Currie, D., Wowk, K., Sack, K., 2013. Ocean in peril: reforming the management of global Ocean living resources in areas beyond national jurisdiction. Mar. Pollut. Bull. 74 (2), 540-551. http://dx.doi.org/10.1016/ j.marpolbul.2013.07.037.

Gómez-Baggethun, E., de Groot, R., Lomas, P.L., Montes, C., 2010. The history of ecosystem services in economic theory and practice: from early notions to markets and payment schemes. Ecol. Econ. 69 (6), 1209-1218. http://dx.doi.org/10.1016/ j.ecolecon.2009.11.007.

GOV.UK, 2016. Museums and galleries monthly visits. 〈https://www.gov.uk/ government/uploads/system/uploads/attachment_data/file/549501/Monthly_ Museums_July_2016_Published_September_2016.xlsx> (accessed 20.10.16).

Grant, S.M., Constable, A., Raymond, B., Doust, S., 2006. Bioregionalisation of the Southern Ocean: Report of Experts Workshop, Hobart, September 2006. World Wide Fund for Nature - Australia (WWF-Australia) and the Antarctic Climate and Ecosystems Cooperative Research Center (ACE CRC), Sydney, Australia.

Grant, S.M., Hill, S.L., Trathan, P.N., Murphy, E.J., 2013. Ecosystem services of the Southern Ocean trade-offs in decision-making. Antarct. Sci. 25, 603-617. http:// dx.doi.org/10.1017/S0954102013000308.

de Groot, R.S., Fisher, B., Christie, M., Aronson, J., Braat, L., Haines-Young, R., Gowdy, J., Maltby, E., Neuville, A., Polasky, S., Portela, R., Ring, I., 2010. Integrating the ecological and economic dimensions in biodiversity and ecosystem service valuation. In: Kumar, P. (Ed.), The Economics of Ecosystems and Biodiversity: Ecological and Economic Foundation. Earthscan, London.

Hattam, C., Atkins, J.P., Beaumont, N., Börger, T., Böhnke-Henrichs, A., Burdon, D., de Groot, R., Hoefnagel, E., Nunes, P.A.L.D., Piwowarczyk, J., Sastre, S., Austen, M.C.,
2015. Marine ecosystem services: linking indicators to their classification. Ecol. Indic. 49, 61-75. http://dx.doi.org/10.1016/j.ecolind.2014.09.026.

Hauck, J., Völker, C., 2015. Southern Ocean $\mathrm{CO}_{2}$ uptake and buffer factor from model run 2012-2100, with links to model results. Supplement to: hauck, J., and Völker, C., 2015. Rising Atmos. $\mathrm{CO}_{2}$ leads Large Impact Biol. South. Ocean $\mathrm{CO}_{2}$ uptake via Chang. Revel. Factor. Geophys. Res. Lett. 42 (5), 1459-1464. http://dx.doi.org/ 10.1002/2015GL063070.

Hellmer, H, Timmermann, R., Determann, J., 2013. Southern Ocean ice shelf melting in a warming climate, CLIVAR WGOMD - SOP Workshop on Sea-Level Rise, Ocean/ Ice shelf Interactions, and Ice Sheets, CSIRO Marine and Atmospheric Research, Hobart, Australia, 18 February 2013 - 20 February 2013

Hoppema, M., 2004a. Weddell Sea turned from source to sink for atmospheric $\mathrm{CO}_{2}$ between pre-industrial time and present. Glob. Planet. Change 40, 219-231. http:// dx.doi.org/10.1016/j.gloplacha.2003.08.001.

Hoppema, M., 2004b. Weddell Sea is a globally significant contributor to deep-Sea sequestration of natural carbon dioxide. Deep-Sea Res. I 51, 1169-1177.

Hoppema, M., Stoll, M.H.C., de Baar, H.J.W., 2000. $\mathrm{CO}_{2}$ in the Weddell Gyre and Antarctic Circumpolar Current: austral autumn and early winter. Mar. Chem. 72 203-220. http://dx.doi.org/10.1016/S0304-4203(00)00082-7.

IAATO, International Association of Antarctic Tour Operators, 2016. Tourism Statistics. 〈http://iaato.org/tourism-statistics〉 (accessed 20.10.16).

IPCC, Intergovernmental Panel on Climate Change, 2014. Polar Regions. Available online: 〈http://www.ipcc.ch/pdf/assessment-report/ar5/wg2/WGIIAR5-Chap28 FINAL.pdf $\rangle$ (accessed 20.10.16)

Jabour-Green, J., Nicol, D., 2003. Bioprospecting in areas outside national jurisdiction: antarctica and the Southern Ocean. Melb., J. Int. Law 4, 76-112.

Jopke, C., Kreyling, J., Maes, J., Koellner, T., 2015. Interactions among ecosystem services across Europe: bagplots and cumulative correlation coefficients reveal synergies, trade-offs, and regional patterns. Ecol. Indic. 49, 46-52. http:// dx.doi.org/10.1016/j.ecolind.2014.09.037, (Available online: http:// www.sciencedirect.com/science/article/pii/S1470160X14004695 (accessed 20.10.16).

Kaleschke, L., Lupkes, C., Vihma, T., Haarpaintner, J., Bochert, A., Hartmann, J., Heygster, G., 2001. SSM/I sea ice remote sensing for mesoscale ocean-atmosphere interaction analysis. Can. J. Remote Sens. 27, 526-537. http://dx.doi.org/10.1080/ 07038992.2001.10854892.

King, D.M., Mazzotta, M.J., 2002. Ecosystem Valuation. Available online: 〈http://www. ecosystemvaluation.org/1-02.htm $>$ (accessed 20.10.16)

Knox, G.A., 2007. Biology of the Southern Ocean. Cambridge University Press, Cambridge, 640.

Koellner, T., 2011. Ecosystem services and global trade of natural resources: an introduction. In: Koellner, T. (Ed.), Ecosystem Services and Global Trade of Natural Resources. Ecology, economics, and policies, Routledge, London, 1-8.

Kremen, C., 2005. Managing ecosystem services: what do we need to know about their ecology? Ecol. Lett. 8, 468-479. http://dx.doi.org/10.1111/j.14610248.2005.00751.x.

Le Quéré, C., Rödenbeck, C., Buitenhuis, E.T., Conway, T.J., Langenfelds, R., Gomez, A., Labuschagne, C., Ramonet, M., Nakazawa, T., Metzl, N., Gillett, N., Heimann, M., 2007. Saturation of The Southern Ocean Co2 sink due to recent climate change. Science 316, 1735-1738. http://dx.doi.org/10.1126/science.1136188.

Ledoux, L., Turner, R.K., 2002. Valuing ocean and coastal resources: a review of practical examples and issues for further action. Ocean Coast. Manag. 45 (9), 583-616. http://dx.doi.org/10.1016/S0964-5691(02)00088-1.

Lenton, A., Tilbrook, B., Law, R.M., Bakker, D., Doney, S.C., Gruber, N., Ishii, M., Hoppema, M., Lovenduski, N.S., Matear, R.J., McNeil, B.I., Metzl, N., Mikaloff Fletcher, S.E., Monteiro, P.M.S., Rödenbeck, C., Sweeney, C., Takahashi, T., 2013. Sea-air $\mathrm{CO}_{2}$ fluxes in the Southern Ocean for the period 1990-2009. Biogeosciences 10, 4037-4054. http://dx.doi.org/10.5194/bg-10-4037-2013.

Linse, K., Griffiths, H.J., Barnes, D.K.A., Clarke, A., 2006. Biodiversity and biogeography of Antarctic and sub-Antarctic mollusca. Deep-Sea Res. II 53, 985-1008.

Locatelli, B., Imbach, B., Wunder, S., 2014. Synergies and trade-offs between ecosystem services in Costa Rica. Environ. Conserv. 41 (1), 27-36. http://dx.doi.org/10.1017/ S0376892913000234.

Lu, G.Y., Wong, D., 2008. An Adaptive Inverse Distance Weighting Spatial Interpolation Technique. Comput. Geosci. 34 (9), 1044-1055. http://dx.doi.org/10.1016/ j.cageo.2007.07.010.

Lynch, H.J., LaRue, M.A., 2014. First global census of the Adelie Penguin. Auk: Ornithol. Adv. 131, 457-466.

Lynch, H.J., Crosbie, K., Fagan, W.F., Naveen, R., 2009. Spatial patterns of tour ship traffic in the Antarctic Peninsula region. Antarct. Sci. 22 (2), 123-130. http:// dx.doi.org/10.1017/S0954102009990654.

Maes, J., Egoh, B.N., Willemen, L., Liquete, C., Vihervaara, P., Schägner, J.P., Grizzetti, B., Drakou, E.G., La Notte, A., Zulian, G., Bouraoui, F., Paracchini, M.L., Braat, L., Bidoglio, G., 2012. Mapping ecosystem services for policy support and decision making in the European Union. Ecosystem Services 1, 31-39.

MEA, Millennium Ecosystem Assessment, 2005a. Ecosystems and Human Well-being: Synthesis. Island Press, Washington, DC.

MEA, Millennium Ecosystem Assessment, 2005b. Marine Fisheries Systems. In: MEA, Millennium Ecosystem Assessment, 2005. Ecosystems and Human Well-being: Current States and Trends. Island Press, Washington, DC.

Melaku Canu, D., Ghermandi, A., Nunes, P.A.L.D., Cossarini, G., Lazzari, P., Solidoro, C. 2015. Estimating the value of carbon sequestration ecosystem services in the Mediterranean Sea: an ecological economics approach. Glob. Environ. Change 32, 87-95. http://dx.doi.org/10.1016/j.gloenvcha.2015.02.008.

Moore, J.K., Abbott, M.R., 2000. Phytoplankton chlorophyll distributions and primary production in the Southern Ocean. J. Geophys. Res. 105, 709-722. 
Murphy, E.J., Cavanagh, R.D., Hofmann, E.E., Hill, S.L., Constable, A.J., Costa, D.P., Pinkerton, M.H., Johnston, N.M., Trathan, P.N., Klinck, J.M., Wolf-Gladrow, D.A., Daly, K.L., Maury, O., Doney, S.C., 2012. Developing integrated models of Southern Ocean food webs: including ecological complexity, accounting for uncertainty and the importance of scale. Prog. Oceanogr. 102, 74-92. http://dx.doi.org/10.1016/ j.pocean.2012.03.006.

Mühlenhardt-Siegel, U., 2011. Cumacean (Peracarida, Crustacea) endemism and faunaloverlap in Antarctic deep-sea basins. Deep Sea Research II 58, 68-73.

Myers, N., Mittermeier, R.A., Mittermeier, C.G., da Fonseca, G.A.B., Kent, J., 2000. Biodiversity hotspots for conservation priorities. Nature 403, 853-858. http:// dx.doi.org/10.1038/35002501.

Nicol, S., Raymond, B., 2012. Pelagic ecosystems in the waters off East Antarctica (30E150E). In: Rogers, A.D., Johnston, N.M., Murphy, E.J., Clarke, A. (Eds.), Antarctic Ecosystems: An Extreme Environment in a Changing World. John Wiley \& Sons, Ltd, Chichester, UK.

O’Connor S. Campbell R., Cortez H.and Knowles T., 2009. Whale Watching Worldwide: tourism numbers, expenditures and expanding economic benefits, a special report from the International Fund for Animal Welfare, Yarmouth MA, USA, prepared by Economists at Large. Available online: 〈http://www.ifaw.org/sites/default/files/ whale_watching_worldwide.pdf $\rangle$ (accessed 20.10.16)

Oceanwide Expeditions, 2015. The A to Z Guide to Cruising the Antarctic. 〈https:// oceanwide-expeditions.com/blog/the-a-to-z-guide-to-cruising-the-antarctic〉 (accessed 20.10.16)

O’Donnell, R., Lewis, N., McIntyre, S., Codon, J., 2011. Improved methods for PCA[HYPHEN]based reconstructions: case study using the Steig et al. (2009) Antarctic temperature reconstruction. Journal of Climate 24, 2099-2115.

Orsi, A.H., Johnson, G.C., Bullister, J.L., 1999. Circulation, mixing, and production of Antarctic Bottom Water. Prog. Oceanogr. 43, 55-109.

Peck, L.S., Barnes, D.K.A., Cook, A.J., Fleming, A.H., Clarke, A., 2010. Negative feedback in the cold: ice retreat produces new carbon sinks in Antarctica. Glob. Change Biol. 16, 2614-2623. http://dx.doi.org/10.1111/j.1365-2486.2009.02071.x.

QGIS Development Team, 2015. QGIS Geographic Information System. Open Source Geospatial Foundation Project. 〈http://qgis.osgeo.org (accessed 20.10.16).

Qiu, J., Turner, M.G., 2013. Spatial interactions among ecosystem services in an urbanizing agricultural watershed. Proc. Natl. Acad. Sci. 110, 12149-12154. http:// dx.doi.org/10.1073/pnas.1310539110.

$\mathrm{R}$ Core Team, 2015. R: A language and environment for statistical computing. R Foundation for Statistical Computing, Vienna, Austria. 〈http://www.R-project.org/〉 (accessed 20.10.16)

Ramaraj, R., Tsai, D.D.W., Chen, P.H., 2013. Chlorophyll is not accurate measurement for algal biomass. Chiang Mai J. Sci. 40, 547-555.

Raudsepp-Hearne, C., Peterson, G.D., Bennett, E.M., 2010. Ecosystem service bundles for analyzing tradeoffs in diverse landscapes. Proc. Natl. Acad. Sci. USA 107, 5242-5247. http://dx.doi.org/10.1073/pnas.0907284107.

Raymond, B., 2011. A circumpolar pelagic regionalisation of the Southern Ocean. Short note submitted for publication to the CCAMLR Workshop on Marine Protected Areas held in Brest, France 2011. Document number: WS-MPA-11/6. Hobart, Australia: Australian Antarctic Division.

Sabine, C.L., Heimann, M., Artaxo, P., Bakker, D.C., Chen, C.T.A., Field, C.B., Gruber, N., Le Quere, C., Prinn, R.G., Richey, J.E., Romero Lankao, P., Sathaye, J.A., Valentini, R., 2004a. Current status and past trends of the global carbon cycle. In: Field, C.B., Raupach, M.R. (Eds.), The Global Carbon Cycle: Integrating Humans, Climate, and the Natural World, SCOPE 62. Island Press, Washington, DC, USA, 17-44.

Sabine, C.L., Feely, R.A., Gruber, N., Key, R.M., Lee, K., Bullister, J.L., Wanninkhof, R., Wong, C.S., Wallace, D.W.R., Tilbrook, B., Millero, F.J., Peng, T.H., Kozyr, A., Ono, T., Rios, A.F., 2004b. The oceanic sink for anthropogenic $\mathrm{CO}_{2}$. Science 305, 367-371.

Sachs, J.D., Reid, W.V., 2006. Environment - investments toward sustainable development. Science 312. http://dx.doi.org/10.1126/science.1124822.

Schägner, J.P., Brander, L., Maes, J., Hartje, V., 2013. Mapping ecosystem services' values: current practice and future prospects. Ecosyst. Serv. 4, 33-46. http:// dx.doi.org/10.1016/j.ecoser.2013.02.003.

Schröter, D., Cramer, W., Leemans, R., Prentice, I.C., Araujo, M.B., Arnell, N.W. Bondeau, A., Bugmann, H., Carter, T.R., Gracia, C.A., de la Vega-Leinert, A.C. Erhard, M., Ewert, F., Glendining, M., House, J.I., Kankaanpaa, S., Klein, R.J.T., Lavorel, S., Lindner, M., Metzger, M.J., Meyer, J., Mitchell, T.D., Reginster, I., Rounsevell, M., Sabate, S., Sitch, S., Smith, B., Smith, J., Smith, P., Sykes, M.T. Thonicke, K., Thuiller, W., Tuck, G., Zaehle, S., Zierl, B., 2005. Ecosystem service supply and vulnerability to global change in Europe. Science 310, 1333-1337, (Doi: 0.1126/science.1115233).

Simpson, R.D., 2011. The Ecosystem Service Framework: a Critical Assessment. Ecosystem Services Economics (ESE), Working Paper Series, UNEP.

Spreen, G., Kaleschke, L., Heygster, G., 2008. Sea ice remote sensing using AMSR-E 89GHz channels. J. Geophys. Res. 113 (C02), C02S03. http://dx.doi.org/10.1029/
2005JC003384.

Stammerjohn, S.E., Martinson, D.G., Smith, R.C., Yuan, X., Rind, D., 2008. Trends in Antarctic annual sea ice retreat and advance and their relation to El Niño - southern oscillation and southern annular mode variability. J. Geophys. Res. 113, C03S90, (Doi: 101029/2007JC004269).

Takahashi, T., Sutherland, S.C., Wanninkhof, R., Sweeney, C., Feely, R.A., Chipman, D.W., Hales, B., Friederich, G., Chavez, F., Watson, A., Bakker, D.C.E., Schuster, U., Metzl, N., Yoshikawa-Inoue, H., Ishii, M., Midorikawa, T., Nojiri, Y., Sabine, C., Olafsson, J., Arnarson, Th.S., Tilbrook, B., Johannessen, T., Olsen, A., Bellerby, R., Körtzinger, A., Metzl, T., Hoppema, M., de Baar, H.J.W., Wong, C.S., Delille, B.,

Bates, N.R., 2009. . Climatological mean and decadal change in surface ocean pCO2, and net sea-air CO2 flux over the global oceans. Deep Sea Res. Part II: Top. Stud. Oceanogr. 56 (8), 554-577. http://dx.doi.org/10.1016/j.dsr2.2008.12.009.

Tallis, H., Kareiva, P., 2005. ecosystem services. Curr. Biol. 15, R746-R748.

Tallis, H., Polasky, S., 2009. Mapping and valuing ecosystem services as an approach for conservation and natural resource management. Ann. N. Y. Acad. Sci. 1162, 265-283. http://dx.doi.org/10.1111/j.1749-6632.2009.04152.x.

TEEB, The Economics of Ecosystems and Biodiversity, 2010. In: Kumar, P. (Ed.), The Economics of Ecosystems and Biodiversity Ecological and Economic Foundations.. Earthscan, London.

TEEB, The Economics of Ecosystems and Biodiversity, 2012. Why Value the Oceans - A discussion paper. Available online: 〈http://www.teebweb.org/media/2013/10/ 2013-Why-Value-the-Oceans-Discussion-Paper.pdf) (accessed 20.10.16).

Teschke, K., Beaver, D., Bester, M.N., Bombosch, A., Bornemann, H., Brandt, A., Brtnik, P., de Broyer, C., Burkhardt, E., Dieckmann, G., Douglass, L., Flores, H., Gerdes, D., Griffiths, H.J., Gutt, J., Hain, S., Hauck, J., Hellmer, H., Herata, H., Hoppema, M., Isla, E., Jerosch, K., Kock, K.-H., Krause, R., Kuhn, G., Lemke, P., Liebschner, A., Linse, K., Miller, H., Mintenbeck, K., Nixdorf, U., Pehlke, H., Petrov, A., Schröder, M., Shust, K.V., Schwegmann, S., Siegel, V., Thomisch, K., Timmermann, R., Trathan, P.N., van de Putte, A., van Franecker, J., van Opzeeland, I.C., von Nordheim, H., Brey, T., 2016a. Scientific background document in support of the development of a CCAMLR MPA in the Weddell Sea (Antarctica) - Version 2016. Part A: General context of the establishment of MPAs and background information on the Weddell Sea MPA planning area. CCAMLR WG-EMM-16/01, 112 pp.

Teschke, K., Pehlke, H., Brey, T., 2016b. Scientific background document in support of the development of a CCAMLR MPA in the Weddell Sea (Antarctica) - Version 2016. Part B: Description of available spatial data. CCAMLR WG-EMM-16/02, 18 pp.

Teschke, K., Pehlke, H., Deininger, M., Jerosch, K., Brey, T., 2016c. Scientific background document in support of the development of a CCAMLR MPA in the Weddell Sea (Antarctica) - Version 2016. Part C: Data analysis and MPA scenario development. CCAMLR WG-EMM-16/03, 78 pp.

Thompson, S.A., Sydeman, W.J., Santora, J.A., Black, B.A., Suryan, R.M., Calmabodkidis, J., Peterson, W.T., Bograd, S.J., 2012. Linking predators to seasonality of upwelling: using food web indicators and path analysis to infer trophic connections. Prog. Oceanogr. 101, 106-120.

Turner, J., Colwell, S.R., Marshall, G.J., Lachlan-Cope, T.A., Carleton, A.M., Jones, P.D., Lagun, V., Reid, P.A., Iagovinka, S., 2005. Antarctic climate change during the last 50 years. International Journal of Climatology 25, 279-294.

UNEP, United Nations Environment Programme, 2010. Global Synthesis. A report from the Regional Seas Conventions and action plans for the Marine Biodiversity Assessment and Outlook Series. United Nations Environment Programme: Regional Seas Programme. Available online: 〈http://icriforum.org/sites/default/files/UNEP \%20Global\%20Synthesis\%20Marine\%20Biodiversity\%20Series.pdf) (accessed 20. 10.16)

UNEP, United Nations Environment Programme, 2011. Managing Trade-offs in Ecosystem Services. Ecosystem Services Economics (ESE), Working Paper Series Environment for Development, Division of Environmental Policy Implementation Paper $\mathrm{N}^{\circ}$ 4. Available online: 〈http://www.bioecon-network.org/pages/UNEP_ publications/04\%20Managing\%20Trade-offs.pdf $\rangle$ (accessed 20.10.16).

Whitehouse, M.J., Meredith, M.P., Rothery, P., Atkinson, A., Ward, P., Korb, R.E., 2008. Rapid warming of the ocean around South Georgia, Southern ocean, during the 20th century: forcing, characteristics and implications for lower trophic levels. Deep Sea Res. I 55, 1218-1228, (Doi: 101016/jdsr200806002).

Wiltshire, J., 2001. Future Prospects for the Marine Minerals Industry. UnderWater Magazine, May/June.

Wolfram Research, 2007. Mathematica Edition, Version 6.0. Wolfram Research, Inc, Champaign, IL.

Zacharias, M.A., Roff, J.C., 2001. Use of focal species in marine conservation and management: a review and critique. Aquat. Conserv.: Mar. Freshw. Ecosyst. 11, 59-76. http://dx.doi.org/10.1002/aqc.429.

Zimmer, I., Wilson, R.P., Gilbert, C., Beaulieu, M., Ancel, A., Plötz, J., 2008. Foraging movements of emperor penguins at Pointe Géologie, Antarctica. Polar Biol. 31, 229-243. http://dx.doi.org/10.1007/s00300-007-0352-5. 